\title{
THE SELF-PERCEPTION OF ATHLETES WITH DISABILITY
}

\author{
Goran Kasum ${ }^{1}$, Marija Mladenović \\ ${ }^{1}$ University of Belgrade, Faculty of Sport and Physical Education, Serbia \\ ${ }^{2}$ Singidunum University, Faculty of Physical Education \& Sports Menagment, Belgrade, Serbia
}

\begin{abstract}
Psychological studies show that people often see those with disabilities in a stereotyped way. Athletes with disabilities are most often seen as "poor" or "superheroes". Apart from their exposure to prejudice and stereotyped social perception, people with disabilities, more often than people without disabilities, face inefficiency in the field of sport. This can result in sport being a double-edged sword, which can improve or impair one's self-image. The aim of this study was to determine how athletes with disabilities see themselves: what is their real self-perception? It was presumed that there are significant differences in terms of the age or gender of the participants. A self-perception inventory was used as an instrument, composed of thirty attributes of personality estimated on a four degree scale. 19 athletes with disabilities aged between 14 and 60 participated in this study. Eight of the participants were younger than 26 years, and 11 were older; there were 14 males and 5 females. The results showed statistically significant differences in self-perception among the participants of different ages or gender. Attributes that dominated among the athletes with disabilities were positive self-perception and a positive self-image (for example, being self-confident, cheerful, relaxed, ambitious, decent). Although the study involved a relatively small number of participants and did not directly consider the correlation between self-perception and sports, the results correspond with the general trend of psychological studies confirming the positive effect of sports activities on the self-concept of people with disabilities.
\end{abstract}

Key words: STEREOTYPE / SOCIAL PERCEPTION / SPORT / SELF-DESCRIPTION

\section{INTRODUCTION}

Whether we are talking about a "disabled person" or "invalid", it is not only a terminological but also a psychological issue. A person becomes an invalid not in the moment when one is diagnosed with a certain type of disability, but when one's uniqueness of psycho-physical functions becomes built into one's self-perception as the main backbone of one's identity (Mladenović, 2015). There are three discourses in the self-description of athletes with disabilities in the literature (Smith, 2015). The first is dominated by sports identity. In this discourse, the athletes describe themselves only in terms of a self-description related to their role in the sport. In the self-description there are only words that describe the person as an athlete, not as a man or a woman, or a person of a certain age, but only as an athlete who practices hard and does everything necessary to achieve success in a sport. It is a self-description of a champion. The second discourse refers to identity that in the foreground contains the fact that the person is first an athlete and then a person with disability. The third discourse involves a self-description which puts the individual's disability ahead of the other characteristics (athletes, people). Such a classification of identity corresponds with the social perception by means of which people see athletes with disabilities as "superheroes" or "poor" (Martin, 2002; 2010). The impression that people establish about others has been the focus of psychological studies for over fifty years and is an important social interaction determinant in sport (Greenlees, 2007).

Social perception is often labeled by stereotypical observation. The social environment is too extensive, too complex and too variable to be studied in its entirety (Stewart, Powell, \& Chetwynd,1979). In order for a person to maintain a balanced image of him/her self and the world, in a situation where information is often 
incomplete, ambiguous and inconsistent, simplified, stereotyped perception occurs (Heider, 1958; Hastorf, Schneider, \& Polefka 1970, Havelka, 1992). Based on a single characteristic, for example, physical disability, the person is attributed a number of other characteristics. Therefore one notable feature then becomes the 'label' for the classification of people in a particular category. Prejudice appears when people agree with a label, the consequences of which are certain emotions and behaviors toward the stigmatized persons. People who are labeled as "different", in everyday life very often encounter restrictions that are not set by their specificities, but by the social environment that treats this uniqueness by means of prejudice (Goffman, 1963; Ostman \& Kjellin, 2002). For example, a person with physical disabilities naturally encounters physical movement barriers and space maladjustment. This may be one reason why a person in a wheelchair, for instance, finds it harder to geta job, although in fact it is those around this individual who make a much bigger barrier of his or her inclusion into everyday life. As a result of a lack of information about a disability or without any real knowledge of the person, people are apt to label individuals with disabilities and developmental disorders as less competent, unreliable, or lacking independence in their job etc. (Shapiro, 1993).

Although the attitude toward athletes with disabilities has substantially changed over the decades at the organizational level (Kasum, 2015; Šiljak, Stefanović, Plakona, Kasum, \& Avdibašić-Vukadinović, 2010; Misener \& Darcy, 2013), there are relatively small number of studies aimed at the psychological exploration of athletes with disabilities in sports psychology (Martin 2002; Kasum, Lazarević, Jakovljević, \& Bačanac, 2011; Perrier \& Smith, 2014; Perrier, Smith, Strachan, \& Latimer-Cheung, 2014; Mladenović, 2015). The way other people perceive athletes with disabilities can greatly affect their self-perception. Even Mead (1934) emphasized the importance of social interaction for the development of self-perception, and William James (1890) pointed out the importance of the self-concept and so-called physical-self. During the developmental period, parents' evaluations are of particular importance. Children who show greater motor skills in very early childhood are often perceived and evaluated by their parents as skillful and advanced, while those who have lesser motor skills, regardless of whether this is related to some kind of disability or not, can cause parents to ascribe their child attributes such as "clumsy" and incompetent for sporting activities.
The observation of motor skills is important for the development of self-perception even in the preschool years. Children aged three to four build a picture of themselves based on what they can do, i.e. based on skills that include fine motor skills. In the period between five and six years old, self-image is more based on interpersonal relationships, i.e. on the question "Who am I in relation to others?" while self-esteem is based on their degree of independence and ability to care for themselves (Perić \& Tišma, 2014). Similar questions of self-effectiveness and self-competence, as well as the reconsideration of self-value and position in the social environment are actualized in adolescence.

For children engaged in sporting activities, important persons who provide information for building their self-image are not only parents, but also other referent adults: a teacher of physical education at school, or a sport coach. The self-perception of one's own body and motor competence is an important foundation in establishing a child's overall self-esteem. The feedback that the child receives from other important persons in the context of the sport situation is very easy to generalize into entire personal competence and it is implanted into the child's self-esteem. A child, who due to certain difficulties in development shows inefficiency in response to environmental stimuli, is likely to be exposed to a negative assessment of his or her own competence. As disability in the developmental period has pervasive or relatively pervasive character, continuously facing personal ineffectiveness and incompetence eventually leads to the construction of a child's self-attributeas "poor". This also leads to lack of self-esteem and causes withdrawal from activities and social interactions (Martin, 2010; 2011; Mladenović, 2015).

With early adolescence, feedback from adults losesits significance, and greater importance is placed on peer evaluation. In the sport context, the period of early adolescence is the time when young people show a decided lack of motivation for sport activities (Mladenović \& Marjanović, 2011). Feedback related to efficiency in sport is a ruthless indicator of transient motor "clumsiness" among young people without developmental disorders, which can cause a transient lack of motivation or even result in their giving up sport. In the case of young people with disabilities and developmental disorders, the sports context can also be another reminder of their own incompetence. Studies show that children with motor disabilities experience failure in the context of sports 
more often than children without disabilities (Smyth \& Anderson, 2000).

The sports field is "fruitful ground" for the development of a positive self-perception and feelings of competence, regardless of whether a person has a disability or not. In fact, there are many studies that show that just through sports, children and adults can improve their self-esteem, develop a positive attitude towards them selves and strengthen the feeling of competence and internal locus of control (Feltz, Short, \& Sullivan, 2008; Deci, 1996; Mladenović, 2010a).

When comparing persons with disabilities who are continuously engaged in physical activities and various sports with people with disabilities who do not take part in sports activities, studies confirm that participation in sports activities significantly increases self-esteem and has a positive effect on the overall self-perception of people with disabilities (Bačanac, Milićević, Kasum, \& Marinković, 2014; Martin, Eklund, \& Adams-Mushett, 1997; Goodwin, Krohn, \& Kuhnle, 2004; Gaskin, Andersen, \& Morris, 2009).

The aim of this study was to determine difference between the real self-perception of younger and older people with disabilities who are actively or recreationally engaged in sports activities. Do they see themselves as superheroes or poor? Since studies show that sport and physical activity positively affects the general self-identification and self-concept, it was assumed that the self-perception was marked by positive attributes. Due to the greater social impact of others in adolescence, it was assumed that with younger participants self-perception was more marked by negative attributes than with older participants (Martin \& Smith, 2002; Martin, 2006; Brown, 2010). According to some studies of self-perception there are differences in self-perception between men and women (Mladenović, 2007), therefore it may be suggested that differences toward gander can be expected too.

\section{METHOD}

\section{Participants}

The study included 19 participants who were athletes with disabilities, 14 males and 5 females, ages from 14 to 60 . The participants were divided into two groups according to their age. One group consisted of participants aged from 14 to $26(\mathrm{~N}=8)$, and in the other group were those aged from 27 to 60 years $(\mathrm{N}=$ 11). They all participated voluntarily in this research.
The participants were athletes with physical disabilities engaged in sporting activities professionally or recreationally. Half of the participants were younger, and half were older than 27 years. The younger participants were active athletes, while the older participants continued to be engaged in sports recreationally after the end of an active sports career. The largest group of participants was made up of those engaged in athletics $(\mathrm{N}=9)$, while the other participants were engaged in different sports (swimming, volleyball, basketball). All participants were members of the Sports Association for Persons with Disabilities from Belgrade, Serbia. They personally agreed to take part in the study, or in the case of minors, with their parents' agreement. The participants were assured that the data they provided about themselves would be anonymous and would be used exclusively for research purposes only.

\section{Instruments}

A self-perception inventory was used in the study that was originally designed for the analysis of self-perception and motivation towards work (Mladenović, 2007). It contained thirty personality traits grouped into six categories (physical characteristics, emotional characteristics, abilities, relations with others, and relationship to oneself, attitude to work and commitments). In the category of physical characteristics there was only one feature (slow), in the category of abilities there were five characteristics, while in each of the other categories there were six personality features. The characteristics were also divided into desirable (positive) and undesirable (negative) attributes. In the category of positive attributes there were eighteen traits (warm, bright, relaxed, self-critical, gifted, confident, cheerful, modest, polite, ambitious, systematic, intelligent, open, practical, reliable, correct, resourceful, self-confident), while in the category of negative attributes there are twelve traits (quarrelsome, gives up easily, weak, slow, envious, self-centered, fearful, irresponsible, anxious, insecure, impulsive, stupid). The participants' task was to assess on a four-point scale (1-not at all; 2-a little, 3 -quite a lot, 4 -very much) which of these characteristics he or she really had.

\section{Data analysis}

The data were analyzed by the SPSS statistical program, version $22^{\text {nd }}$. The descriptive statistics and t-test for independent samples was applied. 
Kasum G., Mladenović M. The self-perception of athletes..., PHYSICAL CULTURE 2017; 71 (1): 43-54

\section{RESULTS}

An examination of the differences in the self-perception of athletes with disabilities in relation to their age shows that there are statistically significant differences between participants age from 14 to $26\left(\mathrm{~N}_{1}=8\right)$ and participants age from 27 to $60\left(\mathrm{~N}_{2}=11\right)$ in terms of characteristic "resourceful". The results are shown in Tables 1 and 2. Participants older than 26 years of age statistically significantly ascribed themselves the attribute of being "resourceful" $(\mathrm{t}=-2.23 ; \mathrm{p}<0.05)$. There were no other significant differences, although there were still attributes that were given average scores of 3 and above 3 by participants in both age groups (relaxed, confident, cheerful, polite, ambitious, adaptive, confident). However, although the result is not statistically significant, it was shown that participants younger than 26 years, on average, were more likely to ascribe to themselves the attributes "warm", "gifted" and "self-centered", while participants older than 26 years gave higher scores to "intelligent" "open", "reliable" and "correct". In terms of the lower average scores (under 2), the participants of different ages agreed with each other only for the attribute "fearful". The participants under 26 years gave low average scores to "non-persistent" and "slow", and participants older than 26 years, to the characteristics "anxious", "uncertain" and "gives up easily". The standard deviation of the self-evaluation of some of the characteristics was above 1 . There were bigger individual differences among the participants younger than 26 years in terms of the self-evaluation of attributes: bright, polite, systematic, intelligent, irresponsible. There was a standard deviation higher than that of the self-description of participants older than 26 years, for the attributes: envious, intelligent and incompetent.

Table 1. Means $(\mathrm{M})$, standard deviations (SD) for different age (14 to 26 years old, $\mathrm{N}_{1}=8 ; 27$ to 60 years old, $\mathrm{N}_{2}=11$ )

\begin{tabular}{lccc}
\hline Feature Age & & M & SD \\
\hline warm & 1 & 3.13 & 0.84 \\
& 2 & 2.80 & 0.92 \\
\hline quarrelsome & 1 & 2.13 & 0.84 \\
& 2 & 2.18 & 0.98 \\
\hline bright & 1 & 2.00 & 1.07 \\
& 2 & 2.82 & 0.97 \\
\hline relaxed & 1 & 3.25 & 0.46 \\
& 2 & 3.45 & 0.69 \\
\hline
\end{tabular}

\begin{tabular}{|c|c|c|c|}
\hline Feature Age & & $\mathbf{M}$ & SD \\
\hline \multirow[t]{2}{*}{ self-critical } & 1 & 2.13 & 0.99 \\
\hline & 2 & 2.45 & 0.93 \\
\hline \multirow[t]{2}{*}{ gives up easily } & 1 & 1.88 & 0.64 \\
\hline & 2 & 1.91 & 0.94 \\
\hline \multirow[t]{2}{*}{ gifted } & 1 & 3.13 & 0.64 \\
\hline & 2 & 2.73 & 0.79 \\
\hline \multirow[t]{2}{*}{ weak } & 1 & 2.13 & 0.84 \\
\hline & 2 & 2.64 & 0.81 \\
\hline \multirow[t]{2}{*}{ confident } & 1 & 3.00 & 0.76 \\
\hline & 2 & 3.36 & 0.67 \\
\hline \multirow[t]{2}{*}{ slow } & 1 & 1.63 & 0.74 \\
\hline & 2 & 2.09 & 0.94 \\
\hline \multirow[t]{2}{*}{ cheerful } & 1 & 3.13 & 0.64 \\
\hline & 2 & 3.18 & 0.84 \\
\hline \multirow[t]{2}{*}{ envious } & 1 & 2.25 & 0.89 \\
\hline & 2 & 1.91 & 1.22 \\
\hline \multirow[t]{2}{*}{ modest } & 1 & 3.00 & 0.54 \\
\hline & 2 & 2.45 & 0.82 \\
\hline \multirow[t]{2}{*}{ polite } & 1 & 3.38 & 1.06 \\
\hline & 2 & 3.00 & 0.63 \\
\hline \multirow[t]{2}{*}{ ambitious } & 1 & 3.13 & 0.99 \\
\hline & 2 & 3.27 & 0.79 \\
\hline \multirow[t]{2}{*}{ systematic } & 1 & 2.75 & 1.04 \\
\hline & 2 & 2.64 & 0.81 \\
\hline \multirow[t]{2}{*}{ self-centered } & 1 & 3.00 & 0.93 \\
\hline & 2 & 2.18 & 0.98 \\
\hline \multirow[t]{2}{*}{ fearful } & 1 & 1.63 & 0.52 \\
\hline & 2 & 1.91 & 0.94 \\
\hline \multirow[t]{2}{*}{ intelligent } & 1 & 2.13 & 1.36 \\
\hline & 2 & 3.00 & 1.18 \\
\hline \multirow[t]{2}{*}{ irresponsible } & 1 & 2.13 & 0.84 \\
\hline & 2 & 2.18 & 0.98 \\
\hline \multirow[t]{2}{*}{ open } & 1 & 2.50 & 0.76 \\
\hline & 2 & 3.09 & 0.54 \\
\hline \multirow[t]{2}{*}{ anxious } & 1 & 2.00 & 0.76 \\
\hline & 2 & 1.82 & 0.60 \\
\hline \multirow[t]{2}{*}{ practical } & 1 & 2.63 & 0.74 \\
\hline & 2 & 2.82 & 0.60 \\
\hline \multirow[t]{2}{*}{ insecure } & 1 & 2.13 & 0.64 \\
\hline & 2 & 1.91 & 0.54 \\
\hline \multirow[t]{2}{*}{ reliable } & 1 & 3.00 & 0.54 \\
\hline & 2 & 3.55 & 0.69 \\
\hline \multirow[t]{2}{*}{ impulsive } & 1 & 2.63 & 0.74 \\
\hline & 2 & 2.45 & 0.82 \\
\hline \multirow[t]{2}{*}{ stupid } & 1 & 2.13 & 0.64 \\
\hline & 2 & 2.09 & 1.04 \\
\hline correct & 1 & 2.75 & 0.70 \\
\hline & 2 & 3.27 & 0.91 \\
\hline
\end{tabular}


Kasum G., Mladenović M. The self-perception of athletes..., PHYSICAL CULTURE 2017; 71 (1): 43-54

\begin{tabular}{llcc}
\hline Feature Age & & M & SD \\
\hline resourceful & 1 & 3.00 & 0.54 \\
& 2 & 3.55 & 0.52 \\
\hline self-confident & 1 & 3.25 & 0.70 \\
& 2 & 3.64 & 0.50 \\
\hline
\end{tabular}

Table 2. t-test for independent samples of personality for different age $\left(\mathrm{N}_{1}=8 ; \mathrm{N}_{2}=11\right)$

\begin{tabular}{|c|c|c|c|c|c|}
\hline Feature & $\mathbf{F}$ & $\mathbf{p}$ & $\mathbf{t}$ & df & $\mathbf{p}$ \\
\hline \multirow[t]{2}{*}{ warm } & 0.01 & 0.94 & 0.78 & 16 & 0.45 \\
\hline & & & 0.79 & 15.69 & 0.45 \\
\hline \multirow[t]{2}{*}{ quarrelsome } & 0.26 & 0.62 & -0.13 & 17 & 0.89 \\
\hline & & & -0.13 & 16.49 & 0.89 \\
\hline \multirow[t]{2}{*}{ bright } & 0.17 & 0.68 & -1.84 & 17 & 0.08 \\
\hline & & & -1.78 & 13.26 & 0.09 \\
\hline \multirow[t]{2}{*}{ relaxed } & 3.16 & 0.09 & -0.72 & 17 & 0.48 \\
\hline & & & -0.77 & 16.95 & 0.45 \\
\hline \multirow[t]{2}{*}{ self-critical } & 0.08 & 0.79 & -0.74 & 17 & 0.47 \\
\hline & & & -0.73 & 14.68 & 0.48 \\
\hline \multirow[t]{2}{*}{ gives up easily } & 0.72 & 0.41 & -0.09 & 17 & 0.93 \\
\hline & & & -0.09 & 16.96 & 0.93 \\
\hline \multirow[t]{2}{*}{ gifted } & 0.41 & 0.53 & 1.17 & 17 & 0.26 \\
\hline & & & 1.21 & 16.70 & 0.24 \\
\hline \multirow[t]{2}{*}{ weak } & 0.03 & 0.96 & -1.34 & 17 & 0.19 \\
\hline & & & -1.34 & 14.95 & 0.20 \\
\hline \multirow[t]{2}{*}{ confident } & 0.17 & 0.69 & -1.10 & 17 & 0.29 \\
\hline & & & -1.08 & 14.13 & 0.29 \\
\hline \multirow[t]{2}{*}{ slow } & 0.05 & 0.83 & -1.16 & 17 & 0.26 \\
\hline & & & -1.20 & 16.83 & 0.25 \\
\hline \multirow[t]{2}{*}{ cheerful } & 0.38 & 0.54 & -0.16 & 17 & 0.89 \\
\hline & & & -0.16 & 16.99 & 0.87 \\
\hline \multirow[t]{2}{*}{ envious } & 1.64 & 0.22 & 0.67 & 17 & 0.51 \\
\hline & & & 0.71 & 16.99 & 0.49 \\
\hline \multirow[t]{2}{*}{ modest } & 5.31 & 0.03 & 1.64 & 17 & 0.12 \\
\hline & & & 1.75 & 16.87 & 0.10 \\
\hline \multirow[t]{2}{*}{ polite } & 2.48 & 0.13 & 0.97 & 17 & 0.35 \\
\hline & & & 0.89 & 10.59 & 0.39 \\
\hline \multirow[t]{2}{*}{ ambitious } & 0.00 & 0.98 & -0.36 & 17 & 0.72 \\
\hline & & & -0.35 & 12.97 & 0.73 \\
\hline \multirow[t]{2}{*}{ systematic } & 2.76 & 0.12 & 0.27 & 17 & 0.79 \\
\hline & & & 0.26 & 12.83 & 0.80 \\
\hline \multirow[t]{2}{*}{ self-centered } & 0.01 & 0.91 & 1.84 & 17 & 0.08 \\
\hline & & & 1.85 & 15.75 & 0.08 \\
\hline \multirow[t]{2}{*}{ fearful } & 0.69 & 0.42 & -0.77 & 17 & 0.45 \\
\hline & & & -0.84 & 16.06 & 0.41 \\
\hline \multirow[t]{2}{*}{ intelligent } & 0.68 & 0.42 & -1.49 & 17 & 0.15 \\
\hline & & & -1.46 & 13.91 & 0.17 \\
\hline \multirow[t]{2}{*}{ irresponsible } & 0.26 & 0.62 & -0.13 & 17 & 0.89 \\
\hline & & & -0.13 & 16.49 & 0.89 \\
\hline
\end{tabular}

\begin{tabular}{lccccc}
\hline Feature & $\mathbf{F}$ & $\mathbf{p}$ & $\mathbf{t}$ & $\mathbf{d f}$ & $\mathbf{p}$ \\
\hline open & 2.64 & 0.12 & -1.99 & 17 & 0.06 \\
& & & -1.89 & 11.99 & 0.08 \\
\hline anxious & 0.07 & 0.80 & 0.58 & 17 & 0.57 \\
& & & 0.56 & 13.03 & 0.58 \\
\hline practical & 1.15 & 0.29 & -0.63 & 17 & 0.54 \\
& & & -0.60 & 13.18 & 0.56 \\
\hline insecure & 0.30 & 0.59 & 0.79 & 17 & 0.44 \\
& & & 0.77 & 13.55 & 0.45 \\
\hline reliable & 3.34 & 0.90 & -1.87 & 17 & 0.08 \\
& & & -1.94 & 16.89 & 0.07 \\
\hline impulsive & 0.09 & 0.77 & 0.47 & 17 & 0.65 \\
& & & 0.47 & 16.06 & 0.64 \\
\hline stupid & 2.92 & 0.11 & 0.08 & 17 & 0.94 \\
& & & 0.09 & 16.66 & 0.93 \\
\hline correct & 0.18 & 0.68 & -1.36 & 17 & 0.19 \\
& & & -1.41 & 16.86 & 0.18 \\
\hline resourceful & 3.13 & 0.09 & -2.23 & 17 & $\mathbf{0 . 0 4}$ \\
& & & -2.22 & 15.02 & $\mathbf{0 . 0 4}$ \\
\hline self-confident & 0.68 & 0.42 & -1.39 & 17 & 0.18 \\
& & & -1.32 & 11.99 & 0.21 \\
\hline
\end{tabular}

The results of the differences in the self-perception of athletes with disabilities in relation to gender are shown in Table 3 and 4. There are significant differences for the characteristics "relaxed" and "introspective", where the significance in favor of the female participants. In terms of the other attributes there are no statistically significant differences between the genders, although men and women gave lower scores (under 2) to different characteristics. For example, men gave low scores to: "non-persistent", "slow", "envious", "fearful" and "uncertain" and women evaluated "anxious" and "incompetent" with low scores. A standard deviation higher than 1 in men occurred only in the case of two attributes (self-centered, intelligent). For female participants there are a number of characteristics with variations in the self-evaluation for more than one standard deviation.

Table 3. Means (M), standard deviations (SD) for different gender (male, $\mathrm{N}_{1}=14$; female, $\mathrm{N}_{2}=5$ )

\begin{tabular}{lccc}
\hline Feature Gender & & M & SD \\
\hline warm & 1 & 2.86 & 0.86 \\
& 2 & 3.25 & 0.98 \\
\hline quarrelsome & 1 & 2.14 & 0.77 \\
& 2 & 2.20 & 1.30 \\
\hline bright & 1 & 2.57 & 0.94 \\
& 2 & 2.20 & 1.30 \\
\hline
\end{tabular}


Kasum G., Mladenović M. The self-perception of athletes..., PHYSICAL CULTURE 2017; 71 (1): 43-54

\begin{tabular}{|c|c|c|c|}
\hline Feature Gender & & M & SD \\
\hline \multirow[t]{2}{*}{ relaxed } & 1 & 3.21 & 0.58 \\
\hline & 2 & 3.80 & 0.45 \\
\hline \multirow[t]{2}{*}{ self-critical } & 1 & 2.07 & 0.83 \\
\hline & 2 & 3.00 & 1.00 \\
\hline \multirow[t]{2}{*}{ gives up easily } & 1 & 1.71 & 0.61 \\
\hline & 2 & 2.40 & 1.14 \\
\hline \multirow[t]{2}{*}{ gifted } & 1 & 2.86 & 0.54 \\
\hline & 2 & 3.00 & 1.23 \\
\hline \multirow[t]{2}{*}{ weak } & 1 & 2.36 & 0.75 \\
\hline & 2 & 2.60 & 1.14 \\
\hline \multirow[t]{2}{*}{ confident } & 1 & 3.14 & 0.77 \\
\hline & 2 & 3.40 & 0.55 \\
\hline \multirow[t]{2}{*}{ slow } & 1 & 1.71 & 0.73 \\
\hline & 2 & 2.40 & 1.14 \\
\hline \multirow[t]{2}{*}{ cheerful } & 1 & 3.21 & 0.58 \\
\hline & 2 & 3.00 & 1.23 \\
\hline \multirow[t]{2}{*}{ envious } & 1 & 1.79 & 0.89 \\
\hline & 2 & 2.80 & 1.30 \\
\hline \multirow[t]{2}{*}{ modest } & 1 & 2.79 & 0.69 \\
\hline & 2 & 2.40 & .89 \\
\hline \multirow[t]{2}{*}{ polite } & 1 & 3.07 & 0.83 \\
\hline & 2 & 3.40 & 0.89 \\
\hline \multirow{2}{*}{ ambitious } & 1 & 3.14 & 0.87 \\
\hline & 2 & 3.40 & 0.89 \\
\hline \multirow[t]{2}{*}{ systematic } & 1 & 2.57 & 0.85 \\
\hline & 2 & 3.00 & 1.00 \\
\hline \multirow[t]{2}{*}{ self-centered } & 1 & 2.57 & 1.02 \\
\hline & 2 & 2.40 & 1.14 \\
\hline \multirow[t]{2}{*}{ fearful } & 1 & 1.71 & 0.61 \\
\hline & 2 & 2.00 & 1.23 \\
\hline \multirow[t]{2}{*}{ intelligent } & 1 & 2.50 & 1.29 \\
\hline & 2 & 3.00 & 1.41 \\
\hline \multirow[t]{2}{*}{ irresponsible } & 1 & 2.14 & .86 \\
\hline & 2 & 2.20 & 1.09 \\
\hline \multirow[t]{2}{*}{ open } & 1 & 2.79 & 0.69 \\
\hline & 2 & 3.00 & 0.71 \\
\hline \multirow[t]{2}{*}{ anxious } & 1 & 2.00 & 0.56 \\
\hline & 2 & 1.60 & 0.89 \\
\hline \multirow[t]{2}{*}{ practical } & 1 & 2.79 & 0.67 \\
\hline & 2 & 2.60 & 0.55 \\
\hline \multirow[t]{2}{*}{ insecure } & 1 & 1.86 & 0.54 \\
\hline & 2 & 2.40 & 0.55 \\
\hline \multirow[t]{2}{*}{ reliable } & 1 & 3.36 & 0.63 \\
\hline & 2 & 3.20 & 0.84 \\
\hline \multirow[t]{2}{*}{ impulsive } & 1 & 2.50 & 0.86 \\
\hline & 2 & 2.60 & 0.55 \\
\hline stupid & 1 & 2.21 & 0.89 \\
\hline & 2 & 1.80 & 0.84 \\
\hline
\end{tabular}

\begin{tabular}{llcc}
\hline Feature Gender & & M & SD \\
\hline correct & 1 & 3.00 & 0.88 \\
& 2 & 3.20 & 0.84 \\
\hline resourceful & 1 & 3.29 & 0.47 \\
& 2 & 3.40 & 0.89 \\
\hline \multirow{2}{*}{ self-confident } & 1 & 3.43 & 0.65 \\
& 2 & 3.60 & 0.55 \\
\hline
\end{tabular}

Table 4. $t$-test for independent samples of personality for different gender (male, $\mathrm{N}_{1}=14$; female, $\mathrm{N}_{2}=5$ )

\begin{tabular}{|c|c|c|c|c|c|}
\hline Feature & $\mathbf{F}$ & $\mathbf{p}$ & t & df & $\mathbf{p}$ \\
\hline \multirow[t]{2}{*}{ warm } & 0.14 & 0.71 & -0.77 & 16 & 0.44 \\
\hline & & & -0.74 & 4.50 & 0.48 \\
\hline \multirow[t]{2}{*}{ quarrelsome } & 2.97 & 0.10 & -0.12 & 17 & 0.91 \\
\hline & & & -0.09 & 5.04 & 0.93 \\
\hline \multirow[t]{2}{*}{ bright } & 0.97 & 0.33 & 0.69 & 17 & 0.50 \\
\hline & & & 0.59 & 5.57 & 0.58 \\
\hline \multirow[t]{2}{*}{ relaxed } & 0.57 & 0.46 & -2.04 & 17 & 0.05 \\
\hline & & & -2.32 & 9.21 & 0.05 \\
\hline \multirow[t]{2}{*}{ self-critical } & 0.75 & 0.40 & -2.04 & 17 & 0.05 \\
\hline & & & -1.86 & 6.09 & 0.11 \\
\hline \multirow[t]{2}{*}{ gives up easily } & 3.37 & 0.08 & -1.71 & 17 & 0.11 \\
\hline & & & -1.28 & 4.85 & 0.26 \\
\hline \multirow[t]{2}{*}{ gifted } & 2.54 & 0.13 & -0.36 & 17 & 0.72 \\
\hline & & & -0.25 & 4.56 & 0.81 \\
\hline \multirow[t]{2}{*}{ weak } & 1.28 & 0.27 & -0.55 & 17 & 0.59 \\
\hline & & & -0.44 & 5.28 & 0.68 \\
\hline \multirow[t]{2}{*}{ confident } & 0.44 & 0.52 & -0.68 & 17 & 0.51 \\
\hline & & & -0.80 & 10.09 & 0.44 \\
\hline \multirow[t]{2}{*}{ slow } & 1.53 & 0.23 & -1.56 & 17 & 0.14 \\
\hline & & & -1.26 & 5.21 & 0.26 \\
\hline \multirow[t]{2}{*}{ cheerful } & 1.78 & 0.20 & 0.53 & 17 & 0.61 \\
\hline & & & 0.38 & 4.66 & 0.72 \\
\hline \multirow[t]{2}{*}{ envious } & 1.59 & 0.22 & -1.94 & 17 & 0.06 \\
\hline & & & -1.61 & 5.40 & 0.16 \\
\hline \multirow[t]{2}{*}{ modest } & 0.97 & 0.34 & 0.99 & 17 & 0.34 \\
\hline & & & 0.87 & 5.85 & 0.42 \\
\hline \multirow[t]{2}{*}{ polite } & 0.40 & 0.54 & -0.75 & 17 & 0.47 \\
\hline & & & -0.72 & 6.64 & 0.49 \\
\hline \multirow[t]{2}{*}{ ambitious } & 0.14 & 0.71 & -0.57 & 17 & 0.58 \\
\hline & & & -0.56 & 6.88 & 0.59 \\
\hline \multirow[t]{2}{*}{ systematic } & 0.15 & 0.70 & -0.93 & 17 & 0.37 \\
\hline & & & -0.85 & 6.21 & 0.43 \\
\hline \multirow[t]{2}{*}{ self-centered } & 0.01 & 0.93 & 0.31 & 17 & 0.76 \\
\hline & & & 0.29 & 6.43 & 0.78 \\
\hline \multirow[t]{2}{*}{ fearful } & 1.31 & 0.27 & -0.69 & 17 & 0.50 \\
\hline & & & -0.50 & 4.73 & 0.64 \\
\hline \multirow[t]{2}{*}{ intelligent } & 0.05 & 0.82 & -0.73 & 17 & 0.48 \\
\hline & & & -0.69 & 6.54 & 0.51 \\
\hline
\end{tabular}




\begin{tabular}{lccccc}
\hline Feature & $\mathbf{F}$ & $\mathbf{p}$ & $\mathbf{t}$ & $\mathbf{d f}$ & $\mathbf{p}$ \\
\hline irresponsible & 1.56 & 0.23 & -0.12 & 17 & 0.91 \\
& & & -0.11 & 5.88 & 0.92 \\
\hline open & 0.52 & 0.48 & -0.59 & 17 & 0.57 \\
& & & -0.58 & 7.02 & 0.58 \\
\hline anxious & 3.41 & 0.08 & 1.18 & 17 & 0.25 \\
& & & 0.94 & 5.15 & 0.39 \\
\hline practical & 0.21 & 0.66 & 0.54 & 17 & 0.60 \\
& & & 0.60 & 9.01 & 0.56 \\
\hline insecure & 0.42 & 0.53 & -1.94 & 17 & 0.07 \\
& & & -1.91 & 6.94 & 0.10 \\
\hline reliable & 0.29 & 0.59 & 0.44 & 17 & 0.66 \\
& & & 0.38 & 5.73 & 0.72 \\
\hline impulsive & 1.43 & 0.25 & -0.24 & 17 & 0.81 \\
& & & -0.30 & 11.35 & 0.77 \\
\hline stupid & 0.06 & 0.81 & 0.90 & 17 & 0.38 \\
& & & 0.93 & 7.53 & 0.38 \\
\hline correct & 0.05 & 0.83 & -0.44 & 17 & 0.66 \\
& & & -0.45 & 7.41 & 0.66 \\
\hline resourceful & 5.38 & 0.03 & -0.37 & 17 & 0.72 \\
& & & -0.27 & 4.81 & 0.80 \\
\hline self-confident & 0.58 & 0.46 & -0.53 & 17 & 0.61 \\
& & & -0.57 & 8.33 & 0.58 \\
\hline
\end{tabular}

Studies into the self-perception and self-concept of people with disabilities have mainly focused on self-esteem, and they make a comparison with persons without disabilities. The results of such research have often shown the negative self-evaluation of persons with disabilities compared to non-disabled people (Bogart, 2014; Crocker \& Major, 1989). The nature of sport, which provides immediate feedback on one's efficiency and competence, can affect the psychological experience of disability in different ways and thus directly and indirectly shape an individual's general self-perception. A study by Lazić and Barić (2013) on athletes with disabilities indicates that active involvement in sport, regardless of the level of competition, gender and age has a positive effect on the entire psycho-physical functioning and acceptance of disability as a component of self-concept.

The results of this study confirm existing findings that sport and physical activity can provide a good "playing field" in life for the development of positive self-perception and optimal psychological functioning.

The attributes most commonly represented in the self-description of athletes with disabilities are: relaxed, confident, cheerful, polite, ambitious, reliable, correct, adoptive and self-confident. On the other hand, attributes that are rarely represented are: non-persistent, slow, fearful and anxious. Such results, even without a causal analysis of the relationship between sport and self-concept, indicate a balanced emotional functioning and emotional stability, self-confidence and focus on the individual's positive potential.

It was presumed that there may be significant differences in terms of the age of the participants, with a less negatively colored stereotypical perception expected in older subjects, i.e. in subjects older than 26 years. The results showed that there are statistically significant differences between the participants, whose age in this study varies from 14-60, in terms of being "resourceful". In addition, there are personality characteristics that are mostly represented by participants younger than 26 years, but not by participants older than 26 , and vice versa. So, with high average scores, participants older than 26 years perceive themselves to be intelligent, open, reliable and correct, while participants under 26 years of age, give high average scores to he attributes "warm", "gifted" and "self-centered". Traits that respondents older than 26 attributed more to themselves are in the category 
of ability (intelligent), relationship with other people (open, correct) and attitude towards work and commitments (reliable). The athletes with disabilities under the age of 26 gave high scores to the characteristics in the categories of abilities (gifted) and in relation to oneself (self-centered), and one in the categories of emotions (warm). Such self-perception matches the descriptions of the main orientation in certain life periods (Erikson, 1994). In adolescence and young adulthood, people are more focused on their potential and personal affirmation, and are even self-centered, while in adulthood the focus goes from oneself to relationship with other people and obligations (reliable). So, young athletes with disabilities, who are actively involved in sport, probably have goals they want to achieve, and are focused on building a relationship with themselves. On the other hand, athletes with disabilities, age from 27 to 60 , have probably already achieved their sporting ambitions, and now they can allow themselves to move their focus onto other people and interpersonal relations (Stevens, 1983). In any case, regardless of their age and developmental needs related to their individual stage of life, all participants showed a positive self-perception.

The generalization of the results obtained in relation to gender seems questionable, considering the very small number of female participants $(\mathrm{N}=5)$. All the qualities that male athletes with disabilities mostly ascribe to themselves, appear in the self-perception of female athletes with disabilities (relaxed, confident, cheerful, polite, ambitious, reliable, correct, adaptive, confident), in addition to which the women ascribe to themselves other characteristics (self-critical, gifted, systematic, intelligent, open). It seems that the self-concept of women is broader and more positive, because far more characteristics are rated with higher average scores than for males. An evaluation of two attributes (relaxed and self-critical) showed that those two attributes are on the border of statistical significance in favor of female athletes with disabilities. If we take into account the characteristic that females evaluated with high scores, and males did not, it seems that women athletes with disabilities are more self-critical and open in approaching self-evaluation, and they also ascribed to themselves more talent and ability than males did. The self-concept of males is narrower, with fewer characteristics rated with high scores, but with more negative traits rated with low scores. In any case, it is important to emphasize the large individual differences among females, but also the small number of participants, thus making it necessary to check the results on a larger sample.

An important implication of this study is that athletes with disabilities have a positive self-perception, which is consistent with descriptions of optimal and mature psychological functioning from the literature in the field of psychology (Rodgers, 1942; Maslow, 1982; Erikson, 1994).

\section{CONCLUSION}

In such literature, there is still very little research dealing with the affirmation of disability as a part of the identity of persons with disabilities, regardless of whether it is congenital or acquired (Dunn \& Burcaw, 2013). An overall positive self-concept and optimal personal functioning (well-being) are not possible if a disability is not acknowledged and included in the personal identity of an individual, and studies show that people with disabilities are often isolated and sent to a circle of people with similar disabilities (Olkin, 2008). Inclusion in the wider social community and society is possible through sport, and improving competence in areas such as sport, can obviously lead to a positive transfer of emotional stability and positive self-perception in other areas, as well as the general self-concept (Martin, 2011; Scarpa, 2011).

This study has some limitations, which should be kept in mind when generalizing the results. Firstly, we examined a relatively small number of participants and a wide range of ages, and the question remains as to whether the same results would obtained if the study involved a larger number of participants and/ or that the participants were from a narrowed age group. It should be borne in mind that the sample was specifically selected, i.e. it was a sample of people who are actively engaged in, or participate in sports and so it is important to be cautious when generalizing the results to persons with disabilities per se. Over the last few decades, physical activity and sport have been promoted in different societies and cultures as a means of maintaining and improving one's psychological and physical health, which is not always applicable to persons with disabilities (Perrier \& Smith, 2014). We should not lose sight that failure in sports activities can further impair the optimal psychological functioning of persons with disabilities and result in the focus shifting onto the disability, therefore strengthening the stereotypical negative self-percep- 
tion (Shilling, 2008). During the study, people with disabilities who have experienced or perceived success and competence in the context of sports shared their views, but the question remains: what would be the self-perception of people with disabilities who have given up sports activities? In this study, the causal link between self-perception and sport was not

\section{REFERENCES}

1. Bačanac, Lj., Milićević-Marinković, B., Kasum, G., \& Marinković, M. (2014). Competitive Anxiety, Self-Confidence and Psychological Skills in Top Athletes With and Without Disabilities: A Pilot Study. Facta univeristatis: Series sport and physical education, 12(2), 59-70.

2. Bandura, A. (1989). Human Agency in Social Cognitive Theory, American Psychologist, 44, 1175-1184.

3. Barič, R., Vlašić, J., \& Cecić-Erpič, S. (2014). Goal orientation and intrinsic motivation for physical education: Does perceived competence matter? Kinesiology, 46(1), 117-126.

4. Bogart, K.R. (2014). The role of disability self-concept in adaptation to congenital or acquired disability. Rehabilitation Psychology, 59(1), 107-115.

5. Brown, R. (2010). Prejudice in social psychology. 2nd edition. UK: Wiley-Blackwell.

6. Chirkov, V.I., Ryan, R.M., Kim, Y., \& Kaplan, U. (2003). Differentiating Autonomy From Individualism and Independence: A Self-Determination Theory Perspective on Internalization of Cultural Orientations and Well-Being. Journal of Personality and Social Psychology, 84, 97-110.

7. Chirkov, V.I., Ryan, R.M., \& Wellness, C. (2005). Cultural Context and Psychological Needs in Canada and Brasil: Testing a Self-Determination Approach to Internalization of Cultural Practices, Identity and Well-Being. Journal of Cross-Cultural Psychology, 36, 423-443.

8. Crocker, J., \& Major, B. (1989). Social stigma and self-esteem: The self-protective properties of stigma. Psychological Review, 96(4), 608-630.

9. DeCharms, R. (1983). Personal Causation, The Internal Affective Determinants of Behavior. Hillsdale, NJ: Lawrence Erlbaum Associates Publishers. studied and the focus of the study was for the participants to present picture of themselves. With the advancement of the metric characteristics of instruments for testing self-perception, further research should consider a causal link between sport and the self-perception of people with disabilities, but also factors that can have a mediating role in this process.

10. Deci, E.L. (1996). Why We Do What We Do: Understanding Self-Motivation. New York: Penguin Books.

11. Deci, E.L. \& Ryan, R.M. (2000). Self-Determination Theory and the Facilitation of Intrinsic Motivation, Social Development and Well-Being. American Psychologist, 55, 68-78.

12. Dunn, D.S., \& Burcaw, S. (2013). Disability identity: Exploring narrative accounts of disability. Rehabilitation Psychology, 58(2), 148-157.

13. Erikson, E. (1994). Identity and the life circe. Reissue edition. New York, NY: W.W.Norton \& Company, Inc.

14. Gaskina, C., Andersen, M.B., \& Morris, T. (2009). Physical activity in the lifeof a woman with severe Cerebral Palsy: Showing competence and beingsocially connected. International Journal of Disability, Development and Education, 56(3), 285-299.

15. Gibson, B.E., Mistry, B., Smith, B., Yoshida, K.K., Abbott, D., Lindsay, S., \& Hamdani, Y. (2014). Becoming man: Gender, disability, and transitioning to adulthood. Health, 18 (1), 95-114.

16. Goodwin, D.L., Krohn, J., \& Kuhnle, A. (2004). Beyond the wheelchair: Theexperience of dance. Adapted Physical Activity Quarterly, 21, 229-247.

17. Greenlees, I. (2007). Person perception and sport performance. In: Jowett, S. \& Lawallee, D. (Eds). Social Psychology in Sport. Champaign, IL: Human Kinetics.

18. Feltz, D.L., Short, S.E., \& Sullivan, P.J. (2008). Self-efficacy in sport. Champaing, IL: Human Kinetics.

19. Goffman, E. (1963). Stigma: Notes on the management of spoiled identity. New York: Touchstone.

20. Hastorf, A.H., Schneider, D.J., \& Polefka, J. (1970). Person perception. Reading, Massachusetts: Addison-Wesley Publishing Company. 
21. Heider, F. (1958). Perceiving the Other Person.In: Tagiuri, R. \& Petrullo, L. (Eds.). Person perception and interpersonal behaviour. Stanford, California: Stanford University Press.

22. Havelka, N. (1992). Socijalna percepcija [Social perception. In Serbian]. Beograd: Zavod za udžbenike i nastavna sredstva.

23. James, W. (1890). The Principles of Psychology. Vol.1 \& Vol.2. At Classics in the History of Psychology, http://psychclassics.yorku.ca

24. Kasum, G. (2015). Sport osoba sa invaliditetom [Sport of persons with disabilities. In Serbian]. Beograd: Fakultet sporta i fizičkog vaspitanja.

25. Kasum, G., Lazarević, Lj., Jakovljević, S. \& Bačanac, Lj. (2011). Personality of male wheelchair basketball players and nonathletes persons with disability. Facta univeristatis: Series sport and physical education, 9(4), 407-415.

26. Lazić, A., \& Barić, R. (2013). Doprinos sporta kvaliteti života sportaša s invaliditetom [Contribution of sport to the quality of life of athletes with disabilities. In Croation]. Hrvatski časopis za javno zdravstvo, 9(33). 244-246

27. Martin, J. (2011). Athletes with disabilities. In Morris, T., \& Terry, P. (Eds). The new sport and exercise psychology companion. Morgantown, WV: Fitness Information Technology.

28. Martin, J. (2010). Psychosocial dynamics of youth disability sport. Sport science review, 19(56), 49-69.

29. Martin, J.J. (2006). Psychosocial aspects of youth disability sport. Adapted Physical Activity Quarterly, 23, 65-77.

30. Martin, J. (2002). Training and performance self-efficacy, affect, and performance in wheelchair road racers. The Sport Psychologist, 16, 384-395.

31. Martin, J.J., \& Smith, K. (2002). Friendship quality in youth disability sport: Perceptions of a best friend. Adapted Physical Activity Quarterly, 19, 472-482.

32. Martin, J.J., Eklund, R.C., \& Adams Mushett, C. (1997). Factor structure oftheathletic identity measurement scale with athletes with disabilities. Adapted Physical Activity Quarterly, 14, 74-82.

33. Maslov, A.(1982). Motivacija i ličnost [Motivation and personality. In Serbian]. Beograd: Nolit.
34. Mead, G.H. (1934). Mind, Self and the Society From the Standpoint of a Social Behaviorist. Chicago: Chicago University Press.

35. Misener, L., \& Darcy, S. (2013). Managing disability sport: From athletes with disabilities to inclusive organizational perspectives. Sport Management Review, 17,1-7.

36. Mladenović, M. (2015). Samoopažanje i motivacija za sport kod osoba sa smetnjama i poremećajma u razvoju [Self-perception and motivation for sport for people with disabilities and developmental disorders. In Serbian]. In: Rapaić, D., Nedović, G. Trunić, N., Lazarević, P., Mladenović, M., Lazarević, S., Antić, N., Miletić, M., i Jovanović, J., Pluridisciplinarity of physical culture for people with disabilities and developmental disorders (pp. 58-85). Beograd: Fakultet za fizičku kulturu i menadzment u sportu, Univerziteta Singidunum.

37. Mladenović, M., \& Marjanović, A. (2011). Some Differences in Sports Motivation of Young Football Players from Russia, Serbia and Montenegro. SportLogia, 7(2), 145-153.

38. Mladenović, M. (2010a). The link of a coach's perception of locus of control and his/her approach to athlets. SportLogia, 6(2), 34-41.

39. Mladenović, M. (2010b). Samomotivacija [Selfmotivation. In Serbian]. Beograd: Zadužbina Andrejević.

40. Mladenović, M. (2007). Predstava o sebi i motivacija $z a$ rad [The image of self and motivation to work. In Serbian]. Beograd: Zadužbina Andrejević.

41. Olkin, R. (2008). Disability-Affirmative Therapy and case formulation: A template for understanding disability in a clinical context. Counseling \& Human Development, 39(8), 1-20.

42. Ostman, M., \& Kjellin, L. (2002) Stigma by association: psychological factors in relatives of people with mental illness. British Journal of Psychiatry, 181, 494-498.

43. Perrier, M-J. \& Smith, B. (2014). Disability, sport and impaired bodies, a critical approach. In: Schindke, R.T, \& McGannon, K.R. The psychology of sub-culture in sport and physical activity: Critical perspectives, (pp. 95-106). London: Routledge. 
44. Perrier, M-J., Smith, B., Strachan, S.M. \& Latimer-Cheung, A.E. (2014). Narratives of athletic identity after aquiring a permanent physical disability. Adapted Physical Activity Quarterly, 31, 106-124.

45. Perić, D., \& Tišma, M. (2014). Uloga motoričkog ponašanja dece predškolskog uzrasta u formiranju pojma o sebi [The role of motor behavior of preschool children in the formation of self-concept. In Serbian]. TIMS Acta, 8(1), 31-40.

46. Rogers, K. (1942). Counceling and Psychotherapy: A Newer Concepts in Practice. Chicago: Houghton and Mifflin Company.

47. Ryan, R.M., \& Deci, E.L. (2006). Self-Regulation and the Problem of Human Autonomy: Does Psychology Needs Choice, Self-Determination and Will? Journal of Personality, 74, 1557-1585.

48. Scarpa, S. (2011). Physical self-concept and self-esteem in adolescents and young adults with and without physical disability: the role of sport participation. European Journal of Adapted Physical Activity, 4(1),38-53.

49. Shapiro, J. (1993). No pity: People with disabilities forging a new civil rights movement. New York, NY: Random House, Inc.
50. Shilling, C. (2008). Changing bodies: Habit, crisis and creativity. London: Sage.

51. Smith, B. (2015). Disability, sport and athletic identity: from a paralympicathlete to retirement and a disabled person. In Schmid, O. \& Seiler, R. (Eds). Proceedings of 14th European Congress of Sport Psychology: Theories and applications for performance, health and humanity. (pp. 229-230). Bern: University of Bern.

52. Smyth, M.M., \& Anderson, H.I. (2000). Coping with clumsiness in the schoolplayground: Social and physical play in children with coordination impairments.British Journal of Developmental Psychology, 18, 389-413.

53. Stevens, R. (1983). Erik Erikson: An introduction. New York: St. Martin's.

54. Stewart, R.A., Powell, G.A., \& Chetwynd, S.J. (1979). Person perception and stereotyping. England: Saxon House

55. Šiljak, V., Stefanović, Đ., Plakona, E., Kasum, G., \& Avdibašić-Vukadinović, N. (2010). Summer paralympic games phenomenon. Physical culture, 64(2), 68-75. 


\section{SELBSTWAHRNEHMUNG BEHINDERTER SPORTLER}

\section{Zusammenfassung}

Psychologische Untersuchungen zeigen, dass andere Menschen sehr oft Personen mit einer Form von Behinderung auf eine stereotypisierte Weise wahrnehmen. Behinderte Sportler werden von anderen Menschen häufig als „jammervoll“ oder als „Superhelden“ erlebt. Neben Vorurteilen und einer stereotypisierten sozialen Wahrnehmung sind behinderte Personen häufiger als nichtbehinderte Personen mit einer Ineffizienz auf dem Sportgelände konfrontiert, womit Sport zu einem zweischneidigen Schwert werden kann, das das Selbstbild fördern oder zerschlagen kann. Das Ziel dieser Untersuchung war es, festzustellen, wie behinderte Sportler sich selbst sehen, wie ihre realistische Selbstwahrnehmung aussieht? Es wurde davon ausgegangen, dass bedeutende Unterschiede auf Grund des Alters und des Geschlechts der Prüflinge vorhanden sein könnten. Als Instrument wurde ein Inventar für Selbstwahrnehmung angewendet, zusammengesetzt aus 30 Persönlichkeitsattributen, die auf einer 4-stüfigen Skala bewertet werden. Befragt wurden 19 behinderte Sportler im Alter von 14 bis 60 Jahren. 8 Prüflinge waren im Alter bis 26 Jahren, 11 waren über 26 Jahre alt; 14 Prüflinge waren Männer, 5 waren Frauen. Die Ergebnisse haben gezeigt, dass statistisch bedeutende Unterschiede in der Selbstwahrnehmung bei Prüflingen unterschiedlichen Alters und Geschlechts vorhanden sind. Die Selbstwahrnehmung der befragten behinderten Sportler wird von Attributen dominiert, die auf eine positive Selbstwahrnehmung und Selbstbild hinweisen (zB. selbstsicher, fröhlich, locker, ehrgeizig, korrekt). Ungeachtet dessen, dass eine relativ kleine Anzahl von Prüflingen an dieser Untersuchung teilnahm und nicht die direkte Verbindung von Selbstwahrnehmung und Sportaktivitäten untersucht wurde, kann man sagen, dass Implikationen vorhanden sind, die im Einklang mit dem allgemeinen Trend von psychologischen Untersuchungen stehen, die einen positiven Einfluss von Sportaktivitäten auf die Verbesserung des Selbstkonzepts von behinderten Personen bestätigen.

Schlüsselwörter: STEREOTYP / SOZIALE WAHRNEHMUNG / SPORT / SELBSTBESCHREIBUNG

The article was carried out as part of the projects: Effects of physical activity applied to locomotion, metabolic, psycho-social and educational status of the population of persons with disability on R Serbia" No. III47015.

Received: 19.02.2017.

Accepted: 27.04.2017. 


\title{
САМОПЕРЦЕПЦИЈА СПОРТИСТА СА ИНВАЛИДИТЕТОМ
}

\author{
Горан Касум, Марија Младеновић² \\ ${ }^{1}$ Универзитет у Београду, Факултет спорта и физичког васпитања \\ ${ }^{2}$ Универзитет Сингидунум, Факултет за физичку културу и менаџмент у спорту
}

\begin{abstract}
Сажетак
Психолошка истраживања показују да други људи врло често опажају особе са инвалидитетом на стереотипан начин. Спортисте са инвалидитетом други најчешће доживљавају или као "јадне" или као "суперхероје". Поред изложености предрасудама и стереотипној социјалној перцепцији, особе са инвалидитетом се, чешће него осоठе ठез инвалидитета, суочавају са неефикасношћу на спортском терену, па тако спорт може бити двосекли мач, који може да унапреди али и наруши слику о себи. Циљ овог истраживања био је да установи како спортисти са инвалидитетом виде сами себе, каква је њихова реална самоперцепција? Претпостављено је да би значајне разлике могле да постоје према старости или полу испитаника. Као инструмент је коришћен Инвентар самоперцепције, састављен од тридесет атрибута личности, који се процењују на четворостепеној скали. Испитано је 19 спортиста са инвалидитетом, старости од 14 до 60 година. Осам испитаника је млађе, а 11 старије од 26 година, 14 мушкараца и 5 жена. Резултати су показали да постоје статистички значајне разлике у самоперцепцији код испитаника различите старости или пола. Самоперцепцијом испитаних спортиста са инвалидитетом доминирају атрибути који указују на позитивну самоперцепцију и слику о себи (нпр. самопоуздан, весео, опуштен, амбициозан, коректан). Иако је у истраживању учествовао релативно мали број испитаника и није испитивана директна повезаност самоперцепције и бављења спортом, може се рећи да постоје импликације које су у складу са општим трендом психолошких истраживања која потврђују позитивно дејство спортских активности на побољшање селф-концепта особа са инвалидитетом.
\end{abstract}

КљУчне речи: СТЕРЕОТИП / СОЦИЈАЛНА ПЕРЦЕПЦИЈА / СПОРТ / САМО-ДЕСКРИПЦИЈА

\section{УВОД}

Да ли је реч о "особи са инвалидитетом" или "инвалиду", није само терминолошко већ и психолошко питање. Особа, “постаје инвалид” не оног тренутка када се дијагностикује одређени тип инвалидитета, већ када своју посебност психофизичког функционисања угради у самоперцепцију, као главну окосницу идентитета (Младеновић, 2015). У самоопису спортиста са инвалидитетом у литератури се наводе три дискурса (Smith, 2015). У првом, доминира спортски идентитет. Спортиста описује себе искључиво кроз самоописе везане за своју улогу у спорту. У самоопису постоје само речи које описују особу као спортисту, не као мушкарца или жену, особу одређене старости, већ само као спортисту, који тренира напорно и чини све што је потребно да би остварио постигнуће у спорту. То је самоопис шампи- она. Други дискурс односи се на идентитет који у првом плану садржи чињеницу да је особа прво спортиста, па потом инвалид. Трећи дискурс, указује на самопопис у којем је у првом плану инвалидност, па тек потом друга обележја (спортиста, особа). Таква класификација идентитета одговара социјалној перцепцији кроз коју други људи виде спортисте са инвалидитетом као "суперхероје" или као "јаднике" (Martin, 2002; 2010). Импресија коју људи формирају о другима особама у фокусу је психолошких истраживања више од педесет година и представља важну детерминанту социјалне интеракције у спорту (Greenlees, 2007).

Социјална перцепција врло често је обележена стереотипним опажањем. Социјална средина је често сувише обимна, сувише комплексна и сувише променљива да би се упознали у потпуности (Stewart, Powell, \& Chetwynd, 1979). Да би особа успела да одржи уравнотежену слику о себи 
и о свету, у ситуацији када су информације врло често непотпуне, двосмислене и неконзистентне, јавља се упрошћено, стереотипно, опажање (Hastorf, Schneider, \& Polefka, 1970; Хавелка, 1992; Heider, 1958). На основу само једне карактеристике, нпр. физичке инвалидности, особи се приписује и низ других особина. Једна истакнута карактеристика, тако, постаје "етикета" за сврставање људи у одређену категорију особа. Предрасуде се појављују када су људи сагласни са етикетирањем и када следствено прихваћеном ставу развијају одређене емоције и понашање према стигматизованим особама. Особе које су означене као "другачије”, врло често наилазе у свакодневном животу на ограничења која им не поставља њихова посебност, већ окружење које ту посебност третира искључиво кроз предрасуде (Goffman, 1963; Ostman \& Kjellin, 2002). На пример, особа са физичким инвалидитетом, сигурно наилази на физичке препреке при кретању и неприлагођеност простора. То може бити један од разлога зашто особа у инвалидским колицима нпр. теже долази до запослења, али много већа препрека укључивању у свакодневицу налази се у људима из окружења. У недостатку информација о врсти сметње и стварном познавању особе, људи су склони да појединце са сметњама и поремећајима у развоју означавају као мање компетентне, непоуздане, несамосталне у послу итд (Shapiro, 1993).

Иако се однос према спортистима са инвалидитетом током деценија у значајној мери променио на организационом нивоу (Касум, 2015; Шиљак, Стефановић, Плакона, Kasum, и Авдибашић-Вукадиновић, 2010; Misener \& Darcy, 2013) у спортској психологији и даље постоји релативно мали број истраживања усмерених на психолошку експлорацију спортиста са инвалидитетом (Martin, 2002; Kasum, Lazarević, Jakovljević, \& Bačanac, 2011; Perrier \& Smith, 2014; Perrier, Smith, Strachan, \& Latimer-Cheung, 2014; Младеновић, 2015). Начин на који други људи опажају спортисте са инвалидитетом може у великој мери да утиче на њихову самоперцепцију. Још је Мед (Mead, 1934) истицао значај социјалне интеракције за развој самоопажања, а Вилијам Џејмс (James, 1890) указивао да је важан аспект селф-концепта и тзв. телесни селф. Током развојног периода од посебног значаја су евалуације које долазе од родитеља. Деца која врло рано у детињству показују већу моторну спретност, врло често су перципирана и евалуирана од родитеља као спретна и напредна у развоју, док мања моторна спретност, без обзира да ли је повезана са неком врстом ометености или не, може да изазове родитеље да приписују детету атрибуте попут "смотан" и некомпетентан за спортске активности.

Опажање моторне спретности значајно је за развој самоперцепције већ на предшколском узрасту. Деца узраста од три до четири године, граде слику о себи на основу онога што могу, односно на основу вештина које подразумевају фину моторику. У периоду између пете и шесте године, слика о себи више се базира на интерперсоналним односима, односно на питању „Ко сам ја у односу на друге?“, док се самопоштовање заснива на степену самосталности и способности за бригу о себи (Perić \& Tišma, 2014). Слична питања сопствене ефикасности и компетенције, као и преиспитивање своје вредности и позиције у социјалном окружењу, актуализују се и у периоду адолесценције.

Током периода детињства, за децу која су укључена у спортске активности, важне друге особе које пружају информације за изградњу слике о себи су не само родитељи, већ и друге референтне одрасле особе: наставник физичког васпитања у школи или спортски тренер. Самоопажање сопственог тела и моторне компетенције је важан темељ у изградњи целокупног самопоштовања. Повратне информације које дете добија од важних других особа у контексту спортске ситуације, врло лако се генерализују на целокупну личну компетенцију и уграђују се у самопоштовање. Дете које услед одређене потешкоће у развоју, показује неефикасност у одговору на срединске подстицаје, највероватније ће бити изложено негативној оцени сопствене компетенције. Како је ометеност у развоју первазивног или релативно первазивног карактера, континуирано суочавање са личном неефикасношћу и некомпетенцијом, временом доводи до изградње само-осећања “јадан”. То надаље доводи до снижавања самопоштовања и проузрокује повлачење из активности и социјалне интеракције (Martin, 2010; 2011; Младеновић, 2015).

Са почетком адолесценције повратне информације од одраслих особа губе приоритет, а већи значај добија вршњачка евалуација. У спортском контексту, период ране адолесценције је време када млади људи показују највише немотивисано- 
сти за бављење спортом (Mladenović \& Marjanović, 2011). Фидбек о спортској ефикасности немилосрдан је показатељ пролазне моторичке "трапавости” код младих без развојних сметњи, што може да проузрокује пролазну немотивисаност или напуштање спорта. У случају младих људи са сметњама и поремећајима у развоју, спортски контекст такође може бити још један подсетник о властитој некомпетенцији. Истраживања показују да деца са моторним тешкоћама чешће доживљавају неуспех у спортском контексту, него деца без тешкоћа у развоју (Smyth \& Anderson, 2000).

Спортски терен је "клизав" за развој позитивног самоопажања и осећања компетенције, без обзира да ли особа поседује инвалидитет или не. Међутим, постоји велики број истраживања која показују да управо кроз бављење спортом, деца и одрасли могу да унапреде самопоштовање, развију позитиван став према себи и ојачају осећање компетентности и унутрашњег локуса контроле (Feltz, Short, \& Sullivan, 2008; Deci, 1996; Mladenović, 2010a).

Када се пореде особе са инвалидитетом, које се континуирано баве физичким активностима и спортом са особама са инвалидитетом које не практикују спортске активности, истраживања потврђују да овладавање спортским активностима значајно увећава самопоштовање и позитивно се одражава на целокупну самоперцепцију особа са инвалидитетом (Bačanac, Milićević-Marinković, Kasum, \& Marinković, 2014; Martin, Eklund, \& Adams-Mushett, 1997; Goodwin, Krohn, \& Kuhnle, 2004; Gaskina, Andersen, \& Morris, 2009).

Циљ овог истраживања био је да се утврди каква је разлика између реалне самоперцепције млађих и старијих особа које се активно или рекреативно баве спортом. Да ли они виде себе као "суперхероје” или као "јадне"? С обзиром да истраживања показују да бављење спортом и физичким активностима позитивно утиче на опште самоосећање и самопоимање, претпостављено је да би самоперцепција била означена позитивним атрибутима. С обзиром на већи социјални утицај других особа у периоду адолесценције, претпоставља се да би код млађих испитаника самоперцепција била више обележена негативним атрибутима, него код старијих испитаника (Martin \& Smith, 2002; Martin, 2006; Brown, 2010). С обзиром да нека истраживања самоперцепције указују на постојање разлика у самоопажању између мушка- раца и жена (Младеновић, 2007), претпостављено је да се могу очекивати и разлике према полу.

\section{МЕТОД}

\section{Узорак испитаника}

У истраживању је учествовало 19 испитаника, спортиста са инвалидитетом, 14 мушкара и 5 жена, старости од 14 до 60 година. У односу на старост, испитаници су подељени у две у групе. Једну групу чинили су испитаници старости од 14 до $26\left(\mathrm{~N}_{1}=8\right)$, а другу испитаници старости од 27 до 60 година $\left(\mathrm{N}_{2}=11\right)$. Учествовање у истраживању било је добровољно. Испитаници су спортисти са телесним инвалидитетом. Спортом се баве професионално или рекреативно. Половина испитаника је млађа, односно старија, од 30 година. Млађи испитаници су активни спортисти, док су старији испитаници по окончању активне спортске каријере наставили да се ठаве спортом рекреативно. Највећи број испитаника бави се атлетиком $(\mathrm{N}=9)$, док се остали испитаници баве различитим спортовима (пливање, одбојка, кошарка). Сви испитаници су чланови Спортског савеза особа са инвалидитетом Београда. Учествовали су у истраживању уз личну сагласност или, у случају малолетних испитаника, уз сагласност родитеља. Испитаницима је наглашено да су подаци које износе о себи анонимни и да ће бити коришћени искључиво у истраживачке сврхе.

\section{Инструменти}

У истраживању је коришћен Self-perception inventory, конструисан оригинално за испитивање односа самоперцепције и мотивације за рад (Младеновић, 2007). Садржи тридесет особина личности сврстаних у шест категорија (физичке особине, емоционалне особине, способности, однос према другима, однос према себи, однос према раду и обавезама). У категорији физичких особина налази се само једна особина (спор), у категорији способности има пет особина, док се у осталим категоријама налази по шест особина личности. Особине су такође подељене на пожељне (позитивне) и непожељне (негативне) аутрибуте. У категорији позитивних атрибута налази се осамнаест особина ( $\bar{u} о \bar{u} а о, \delta и с \bar{u} а р$, ойyшиене, самокриииччан, наgарен, самойоуздан, весео, скроман, учиичв, амбициозан, систиематичан, 


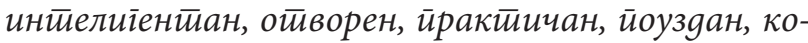
рекйан, сналажљив, самоуверен), док категорија негативних атрибута садржи дванаест особина (сваяльив, неистирајан, ииоиустиљив, сӣор, завияльив, самољубив, итлаштив, неодіоворан, нервозан, несиіуран, имйулсиван, ілуй). Задатак испитаника је, да на четворостепеној скали (1-нимало; 2-мало; 3-прилично; 4-веома много), процени у којој мери мисли да реално поседује сваку особину.

\section{Обрада података}

Подаци су обрађени статистичким програмом СПСС, верзија 22. Примењена је дескриптивна статистика и т-тест за независне узорке.

\section{РЕЗУЛТАТИ}

Испитивање разлика у самоперцепцији спортиста са инвалидитетом у односу на године старости показује да постоје статистички значајне разлике између испитаника старости од 14 до 26 година $\left(\mathrm{N}_{1}=8\right)$ и испитаника старости од 27 до 60 година $\left(\mathrm{N}_{2}=11\right)$, у односу на особину сналажлив. Резултати су приказани у Табели 1 и 2. Испитаници старији од 26 година статистички значајније приписују себи особину сналажльи ( $t=-2.23$; $p<0.05)$. Других значајних разлика нема, али постоје особине које су оцењене просечним оценама 3 и преко 3, код испитаника из обе старосне групе (ойушйен, самойоуздан, весео, учӣив, амбициозан, сналажтьв, самоуверен). Међутим, иако није статистички значајно показало се да испитаници стари до 26 година у просеку више себи приписују атрибуте йойао, наgарен и самољубив, док испитаници старији од 26 година вишим оценама процењују особине, иниеелиіенйан, ойворен, йоузан и корекйан. У погледу нижих просечних оцена (испод 2), испитаници различите старости слажу се само у случају атрибута йлашљив. Испитаници млађи од 26 година ниске просечне оцене дају особинама неистирајан и сйор, а испитаници старији од 26 година особинама нервозан, несиіу ран и неистирајан. Стандардне девијације у самопроценама неких особина износе преко 1. Beће индивидуалне разлике код испитаника млађих од 26 година постоје у погледу самопроцене атрибу-

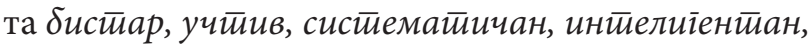
неоgіоворан. У самоопису испитаника старијих од 26 година појављује се стандардна девијација већа од један у случају особина завияльив, иниеелиіен-

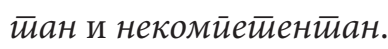

Табела 1. Аритметичка средина (М) и стандарда девијација (СД) по узрасту (1= 14-26 година; 2=11, 27-60 г.)

\begin{tabular}{|c|c|c|c|}
\hline Особина године & & $\mathbf{M}$ & СД \\
\hline \multirow[t]{2}{*}{ топао } & 1 & 3.13 & 0.84 \\
\hline & 2 & 2.80 & 0.92 \\
\hline \multirow[t]{2}{*}{ свадљив } & 1 & 2.13 & 0.84 \\
\hline & 2 & 2.18 & 0.98 \\
\hline \multirow[t]{2}{*}{ бистар } & 1 & 2.00 & 1.07 \\
\hline & 2 & 2.82 & 0.97 \\
\hline \multirow[t]{2}{*}{ опуштен } & 1 & 3.25 & 0.46 \\
\hline & 2 & 3.45 & 0.69 \\
\hline \multirow[t]{2}{*}{ самокритичан } & 1 & 2.13 & 0.99 \\
\hline & 2 & 2.45 & 0.93 \\
\hline \multirow[t]{2}{*}{ неистрајан } & 1 & 1.88 & 0.64 \\
\hline & 2 & 1.91 & 0.94 \\
\hline \multirow[t]{2}{*}{ надарен } & 1 & 3.13 & 0.64 \\
\hline & 2 & 2.73 & 0.79 \\
\hline \multirow[t]{2}{*}{ попустљив } & 1 & 2.13 & 0.84 \\
\hline & 2 & 2.64 & 0.81 \\
\hline \multirow[t]{2}{*}{ самопоуздан } & 1 & 3.00 & 0.76 \\
\hline & 2 & 3.36 & 0.67 \\
\hline \multirow[t]{2}{*}{ спор } & 1 & 1.63 & 0.74 \\
\hline & 2 & 2.09 & 0.94 \\
\hline \multirow[t]{2}{*}{ весео } & 1 & 3.13 & 0.64 \\
\hline & 2 & 3.18 & 0.84 \\
\hline \multirow[t]{2}{*}{ завидљив } & 1 & 2.25 & 0.89 \\
\hline & 2 & 1.91 & 1.22 \\
\hline \multirow[t]{2}{*}{ скроман } & 1 & 3.00 & 0.54 \\
\hline & 2 & 2.45 & 0.82 \\
\hline \multirow[t]{2}{*}{ учтив } & 1 & 3.38 & 1.06 \\
\hline & 2 & 3.00 & 0.63 \\
\hline \multirow[t]{2}{*}{ амбициозан } & 1 & 3.13 & 0.99 \\
\hline & 2 & 3.27 & 0.79 \\
\hline \multirow[t]{2}{*}{ систематичан } & 1 & 2.75 & 1.04 \\
\hline & 2 & 2.64 & 0.81 \\
\hline \multirow[t]{2}{*}{ самољубив } & 1 & 3.00 & 0.93 \\
\hline & 2 & 2.18 & 0.98 \\
\hline \multirow[t]{2}{*}{ плашљив } & 1 & 1.63 & 0.52 \\
\hline & 2 & 1.91 & 0.94 \\
\hline \multirow[t]{2}{*}{ интелигентан } & 1 & 2.13 & 1.36 \\
\hline & 2 & 3.00 & 1.18 \\
\hline \multirow[t]{2}{*}{ неодговоран } & 1 & 2.13 & 0.84 \\
\hline & 2 & 2.18 & 0.98 \\
\hline \multirow[t]{2}{*}{ отворен } & 1 & 2.50 & 0.76 \\
\hline & 2 & 3.09 & 0.54 \\
\hline
\end{tabular}


Касум Г., Младеновић М. Самоперцепција спортиста..., ФИЗИЧКА КУЛТУРА 2017; 71 (1): $43-54$

\begin{tabular}{lccc}
\hline Особина године & & M & СД \\
\hline нервозан & 1 & 2.00 & 0.76 \\
& 2 & 1.82 & 0.60 \\
\hline практичан & 1 & 2.63 & 0.74 \\
& 2 & 2.82 & 0.60 \\
\hline несигуран & 1 & 2.13 & 0.64 \\
\hline поуздан & 2 & 1.91 & 0.54 \\
\hline импулсиван & 1 & 3.00 & 0.54 \\
& 2 & 3.55 & 0.69 \\
\hline некомпетентан & 1 & 2.63 & 0.74 \\
& 2 & 2.45 & 0.82 \\
\hline коректан & 2 & 2.13 & 0.64 \\
& 1 & 2.09 & 1.04 \\
\hline сналажљив & 2 & 2.75 & 0.70 \\
& 1 & 3.27 & 0.91 \\
\hline самоуверен & 2 & 3.00 & 0.54 \\
& 1 & 3.55 & 0.52 \\
\hline
\end{tabular}

\begin{tabular}{|c|c|c|c|c|c|}
\hline Особина & $\mathbf{F}$ & p & $\mathbf{t}$ & df & $\mathbf{p}$ \\
\hline & & & 1.75 & 16.87 & 0.10 \\
\hline \multirow[t]{2}{*}{ учтив } & 2.48 & 0.13 & 0.97 & 17 & 0.35 \\
\hline & & & 0.89 & 10.59 & 0.39 \\
\hline \multirow[t]{2}{*}{ амбициозан } & 0.00 & 0.98 & -0.36 & 17 & 0.72 \\
\hline & & & -0.35 & 12.97 & 0.73 \\
\hline \multirow[t]{2}{*}{ системат } & 2.76 & 0.12 & 0.27 & 17 & 0.79 \\
\hline & & & 0.26 & 12.83 & 0.80 \\
\hline \multirow[t]{2}{*}{ самољубив } & 0.01 & 0.91 & 1.84 & 17 & 0.08 \\
\hline & & & 1.85 & 15.75 & 0.08 \\
\hline \multirow[t]{2}{*}{ плашљив } & 0.69 & 0.42 & -0.77 & 17 & 0.45 \\
\hline & & & -0.84 & 16.06 & 0.41 \\
\hline \multirow[t]{2}{*}{ интелигентан } & 0.68 & 0.42 & -1.49 & 17 & 0.15 \\
\hline & & & -1.46 & 13.91 & 0.17 \\
\hline \multirow[t]{2}{*}{ неодговор } & 0.26 & 0.62 & -0.13 & 17 & 0.89 \\
\hline & & & -0.13 & 16.49 & 0.89 \\
\hline \multirow[t]{2}{*}{ отворен } & 2.64 & 0.12 & -1.99 & 17 & 0.06 \\
\hline & & & -1.89 & 11.99 & 0.08 \\
\hline \multirow[t]{2}{*}{ нервозан } & 0.07 & 0.80 & 0.58 & 17 & 0.57 \\
\hline & & & 0.56 & 13.03 & 0.58 \\
\hline \multirow[t]{2}{*}{ практичан } & 1.15 & 0.29 & -0.63 & 17 & 0.54 \\
\hline & & & -0.60 & 13.18 & 0.56 \\
\hline \multirow[t]{2}{*}{ несигуран } & 0.30 & 0.59 & 0.79 & 17 & 0.44 \\
\hline & & & 0.77 & 13.55 & 0.45 \\
\hline \multirow[t]{2}{*}{ поуздан } & 3.34 & 0.90 & -1.87 & 17 & 0.08 \\
\hline & & & -1.94 & 16.89 & 0.07 \\
\hline \multirow[t]{2}{*}{ импулсиван } & 0.09 & 0.77 & 0.47 & 17 & 0.65 \\
\hline & & & 0.47 & 16.06 & 0.64 \\
\hline \multirow[t]{2}{*}{ некомпетентан } & 2.92 & 0.11 & 0.08 & 17 & 0.94 \\
\hline & & & 0.09 & 16.66 & 0.93 \\
\hline \multirow[t]{2}{*}{ коректан } & 0.18 & 0.68 & -1.36 & 17 & 0.19 \\
\hline & & & -1.41 & 16.86 & 0.18 \\
\hline \multirow[t]{2}{*}{ сналажљив } & 3.13 & 0.09 & -2.23 & 17 & 0.04 \\
\hline & & & -2.22 & 15.02 & 0.04 \\
\hline \multirow[t]{2}{*}{ самоуверен } & 0.68 & 0.42 & -1.39 & 17 & 0.18 \\
\hline & & & -1.32 & 11.99 & 0.21 \\
\hline
\end{tabular}

Резултати испитивања разлика у самоперцепцији спортиста са инвалидитетом у односу на пол приказани су у Табели 3 и 4 . Постоје статистички значајне разлике у погледу особина ойушйен и самокриииччиан, где је значајност у корист испитаника женског пола. У погледу осталих атрибута нема статистички значајних разлика између полова, али различитим особинама мушкарци и жене дају ниже просечне оцене (испод 2). На пример, мушкарци ниским оценама процењују атрибуте неисйрајан, сйор, завиялив, йлашљив, 
Касум Г., Младеновић М. Самоперцепција спортиста..., ФИЗИЧКА КУЛТУРА 2017; 71 (1): 43-54

несиіуран. Жене себи ниском просечном оценом приписују особине нервозан и некомиететенйан. Сандардна девијација (СД) већа од 1, код мушкараца се појављује само у случају два атрибута (самољубив, иниеелиіенйан). Код испитаника женског пола постоји већи број особина на којима су варијације у самопроцени веће од једне стандардне девијације.

Табела 3. Аритметичка средина (М) и стандарда девијација (СД) по половима (1-мушки, $\mathrm{N}_{1}=14$; женски, $\mathrm{N}_{2}=5$ )

\begin{tabular}{|c|c|c|c|}
\hline Особина Пол & & $\mathbf{M}$ & СД \\
\hline \multirow[t]{2}{*}{ топао } & 1 & 2.86 & 0.86 \\
\hline & 2 & 3.25 & 0.98 \\
\hline \multirow[t]{2}{*}{ свадљив } & 1 & 2.14 & 0.77 \\
\hline & 2 & 2.20 & 1.30 \\
\hline \multirow[t]{2}{*}{ бистар } & 1 & 2.57 & 0.94 \\
\hline & 2 & 2.20 & 1.30 \\
\hline \multirow[t]{2}{*}{ опуштен } & 1 & 3.21 & 0.58 \\
\hline & 2 & 3.80 & 0.45 \\
\hline \multirow[t]{2}{*}{ самокритичан } & 1 & 2.07 & 0.83 \\
\hline & 2 & 3.00 & 1.00 \\
\hline \multirow[t]{2}{*}{ неистрајан } & 1 & 1.71 & 0.61 \\
\hline & 2 & 2.40 & 1.14 \\
\hline \multirow[t]{2}{*}{ надарен } & 1 & 2.86 & 0.54 \\
\hline & 2 & 3.00 & 1.23 \\
\hline \multirow[t]{2}{*}{ попустљив } & 1 & 2.36 & 0.75 \\
\hline & 2 & 2.60 & 1.14 \\
\hline \multirow[t]{2}{*}{ самопоуздан } & 1 & 3.14 & 0.77 \\
\hline & 2 & 3.40 & 0.55 \\
\hline \multirow[t]{2}{*}{ спор } & 1 & 1.71 & 0.73 \\
\hline & 2 & 2.40 & 1.14 \\
\hline \multirow[t]{2}{*}{ весео } & 1 & 3.21 & 0.58 \\
\hline & 2 & 3.00 & 1.23 \\
\hline \multirow[t]{2}{*}{ завидљив } & 1 & 1.79 & 0.89 \\
\hline & 2 & 2.80 & 1.30 \\
\hline \multirow[t]{2}{*}{ скроман } & 1 & 2.79 & 0.69 \\
\hline & 2 & 2.40 & .89 \\
\hline \multirow[t]{2}{*}{ учтив } & 1 & 3.07 & 0.83 \\
\hline & 2 & 3.40 & 0.89 \\
\hline \multirow[t]{2}{*}{ амбициозан } & 1 & 3.14 & 0.87 \\
\hline & 2 & 3.40 & 0.89 \\
\hline \multirow[t]{2}{*}{ систематичан } & 1 & 2.57 & 0.85 \\
\hline & 2 & 3.00 & 1.00 \\
\hline \multirow[t]{2}{*}{ самољубив } & 1 & 2.57 & 1.02 \\
\hline & 2 & 2.40 & 1.14 \\
\hline \multirow[t]{2}{*}{ плашљив } & 1 & 1.71 & 0.61 \\
\hline & 2 & 2.00 & 1.23 \\
\hline
\end{tabular}

\begin{tabular}{lccc}
\hline Особина Пол & & М & СД \\
\hline интелигентан & 1 & 2.50 & 1.29 \\
& 2 & 3.00 & 1.41 \\
\hline неодговоран & 1 & 2.14 & .86 \\
\hline отворен & 2 & 2.20 & 1.09 \\
\hline нервозан & 1 & 2.79 & 0.69 \\
& 2 & 3.00 & 0.71 \\
\hline практицан & 1 & 2.00 & 0.56 \\
\hline несигуран & 2 & 1.60 & 0.89 \\
\hline поуздан & 1 & 2.79 & 0.67 \\
& 2 & 2.60 & 0.55 \\
\hline импулсиван & 1 & 1.86 & 0.54 \\
& 1 & 2.40 & 0.55 \\
\hline некомпетентан & 1 & 3.36 & 0.63 \\
& 2 & 3.20 & 0.84 \\
\hline коректан & 2 & 2.50 & 0.86 \\
& 1 & 2.60 & 0.55 \\
\hline сналажљив & 2 & 2.21 & 0.89 \\
\hline самоуверен & 1 & 3.80 & 0.84 \\
\hline
\end{tabular}

Табела 4. t-тест за независне узорке према полу: мушки $\left(\mathrm{N}_{1}=14\right)$, жене $\left(\mathrm{N}_{2}=5\right)$

\begin{tabular}{lccccc}
\hline Особина & $\mathbf{F}$ & $\mathbf{p}$ & $\mathbf{t}$ & $\mathbf{d f}$ & $\mathbf{p}$ \\
\hline топао & 0.14 & 0.71 & -0.77 & 16 & 0.44 \\
& & & -0.74 & 4.50 & 0.48 \\
\hline свадљив & 2.97 & 0.10 & -0.12 & 17 & 0.91 \\
& & & -0.09 & 5.04 & 0.93 \\
\hline бистар & 0.97 & 0.33 & 0.69 & 17 & 0.50 \\
& & & 0.59 & 5.57 & 0.58 \\
\hline опуштен & 0.57 & 0.46 & -2.04 & 17 & $\mathbf{0 . 0 5}$ \\
& & & -2.32 & 9.21 & $\mathbf{0 . 0 5}$ \\
\hline самокритичан & 0.75 & 0.40 & -2.04 & 17 & $\mathbf{0 . 0 5}$ \\
& & & -1.86 & 6.09 & 0.11 \\
\hline неистрајан & 3.37 & 0.08 & -1.71 & 17 & 0.11 \\
& & & -1.28 & 4.85 & 0.26 \\
\hline надарен & 2.54 & 0.13 & -0.36 & 17 & 0.72 \\
& & & -0.25 & 4.56 & 0.81 \\
\hline попустљив & 1.28 & 0.27 & -0.55 & 17 & 0.59 \\
& & & -0.44 & 5.28 & 0.68 \\
\hline самопоуздан & 0.44 & 0.52 & -0.68 & 17 & 0.51 \\
& & & -0.80 & 10.09 & 0.44 \\
\hline спор & 1.53 & 0.23 & -1.56 & 17 & 0.14
\end{tabular}




\begin{tabular}{|c|c|c|c|c|c|}
\hline Особина & $\mathbf{F}$ & $\mathbf{p}$ & $t$ & df & p \\
\hline & & & -1.26 & 5.21 & 0.26 \\
\hline \multirow[t]{2}{*}{ весео } & 1.78 & 0.20 & 0.53 & 17 & 0.61 \\
\hline & & & 0.38 & 4.66 & 0.72 \\
\hline \multirow[t]{2}{*}{ завидљив } & 1.59 & 0.22 & -1.94 & 17 & 0.06 \\
\hline & & & -1.61 & 5.40 & 0.16 \\
\hline \multirow[t]{2}{*}{ скроман } & 0.97 & 0.34 & 0.99 & 17 & 0.34 \\
\hline & & & 0.87 & 5.85 & 0.42 \\
\hline \multirow[t]{2}{*}{ учтив } & 0.40 & 0.54 & -0.75 & 17 & 0.47 \\
\hline & & & -0.72 & 6.64 & 0.49 \\
\hline \multirow[t]{2}{*}{ амбициозан } & 0.14 & 0.71 & -0.57 & 17 & 0.58 \\
\hline & & & -0.56 & 6.88 & 0.59 \\
\hline \multirow[t]{2}{*}{ систематичан } & 0.15 & 0.70 & -0.93 & 17 & 0.37 \\
\hline & & & -0.85 & 6.21 & 0.43 \\
\hline \multirow[t]{2}{*}{ самољубив } & 0.01 & 0.93 & 0.31 & 17 & 0.76 \\
\hline & & & 0.29 & 6.43 & 0.78 \\
\hline \multirow[t]{2}{*}{ плашљив } & 1.31 & 0.27 & -0.69 & 17 & 0.50 \\
\hline & & & -0.50 & 4.73 & 0.64 \\
\hline \multirow[t]{2}{*}{ интелигентан } & 0.05 & 0.82 & -0.73 & 17 & 0.48 \\
\hline & & & -0.69 & 6.54 & 0.51 \\
\hline \multirow[t]{2}{*}{ неодговоран } & 1.56 & 0.23 & -0.12 & 17 & 0.91 \\
\hline & & & -0.11 & 5.88 & 0.92 \\
\hline \multirow[t]{2}{*}{ отворен } & 0.52 & 0.48 & -0.59 & 17 & 0.57 \\
\hline & & & -0.58 & 7.02 & 0.58 \\
\hline \multirow[t]{2}{*}{ нервозан } & 3.41 & 0.08 & 1.18 & 17 & 0.25 \\
\hline & & & 0.94 & 5.15 & 0.39 \\
\hline \multirow[t]{2}{*}{ практичан } & 0.21 & 0.66 & 0.54 & 17 & 0.60 \\
\hline & & & 0.60 & 9.01 & 0.56 \\
\hline \multirow[t]{2}{*}{ несигуран } & 0.42 & 0.53 & -1.94 & 17 & 0.07 \\
\hline & & & -1.91 & 6.94 & 0.10 \\
\hline \multirow[t]{2}{*}{ поуздан } & 0.29 & 0.59 & 0.44 & 17 & 0.66 \\
\hline & & & 0.38 & 5.73 & 0.72 \\
\hline \multirow[t]{2}{*}{ импулсиван } & 1.43 & 0.25 & -0.24 & 17 & 0.81 \\
\hline & & & -0.30 & 11.35 & 0.77 \\
\hline \multirow[t]{2}{*}{ некомпетентан } & 0.06 & 0.81 & 0.90 & 17 & 0.38 \\
\hline & & & 0.93 & 7.53 & 0.38 \\
\hline \multirow[t]{2}{*}{ коректан } & 0.05 & 0.83 & -0.44 & 17 & 0.66 \\
\hline & & & -0.45 & 7.41 & 0.66 \\
\hline \multirow[t]{2}{*}{ сналажљив } & 5.38 & 0.03 & -0.37 & 17 & 0.72 \\
\hline & & & -0.27 & 4.81 & 0.80 \\
\hline \multirow[t]{2}{*}{ самоуверен } & 0.58 & 0.46 & -0.53 & 17 & 0.61 \\
\hline & & & -0.57 & 8.33 & 0.58 \\
\hline
\end{tabular}

\section{ДИСКУСИЈА}

Веровање о постојању капацитета личности за оптимално лично функционисање, психички раст и развој, емоционалну стабилност, интегрисаност и виталност, није само теоријско већ и практично питање, без обзира да ли је реч о особама са или без инвалидитета. Класичан аристотеловски поглед на људску природу претпоставља да човек поседује природну тенденцију ка психичком расту и интеграцији. Људи природно траже изазове, развијају интересовања, откривају нове могућности и активно интернализујусоцијалне утицаје (Младеновић, 2010б). Истраживања су показала да сви људи без обзира на индивидуалне разлике показују тенденцију да остваре аутентично и аутономно функционисање, да се осећају компетентено и прихваћено од своје околине (De Charms, 1983; Bandura, 1989; Deci \& Ryan, 2000; Chirkov, Ryan, Kim, \& Kaplan, 2003; Chirkov, Ryan, Wellness, 2005; Ryan \& Deci, 2006; Barić, Vlašić, \& Cecić-Erpič, 2014). Без обзира да ли је инвалидност присутна од рођења или је стечена, важно интрапсихичко питање односи се на самоперцепцију, осећање личне одговорности и кривице за своје стање (Gibson et al, 2013).

Истраживања самоперцепције и селф-концепта особа са инвалидитетом, углавном су се бавила испитивањем самопоштовања и поређењем са особама ठез инвалидитета. Негативније самоевалуације особа са инвалидитетом у односу на особе без инвалидитета, обично су били резултати таквих истраживања (Bogart, 2014; Crocker \& Major, 1989). Природа спорта који моментално пружа повратну информацију о ефикасности и компетенцији, може на различите начине да утиче на психички доживљај инвалидности и тако директно и индиректно обликује генералну самоперцепцију. Постоје истраживања на спортистима са инвалидитетом, која указују да активно бављење спортом, без обзира на ниво такмичења, пол и старост, позитивно утиче на целокупно психофизичко функционисање и прихватање инвалидности као саставног дела селф-концепта (Lazić \& Barić, 2013).

Резултати овог истраживања придружују се постојећим налазима да спорт и физичке активности могу да представљају добар животни терен за развој позитивне самоперцепције и оптималног психичког функционисања.

Атрибути који су у највећој мери заступљени у самоопису спортиста са инвалидитетом су: ойyшиеиен, самойоуздан, весео, учйив, амбициозан, ӣоузяан, корекииан, сналажлив и самоуверен. С друге 
стране, у најмањој мери заступљени су атрибути неистирајан, сиоор, йлаштьив и нервозан. Такви резултати, чак и без каузалне анализе повезаности спорта и селф-концепта, указују на уравнотежено емоционално функционисање и емоционалну стабилност, сигурност у себе и усмереност на властите позитивне потенцијале.

Претпостављено је да би значајне разлике могле да постоје у погледу старости испитаника и да да се мања обојеност негативним стереотипним опажањем очекује код старијих испитаника, тј. код испитаника старијих од 26 година. Резултати су показали да статистички значајних разлика између испитаника, чија старост у овом истраживању варира од 14 до 60 година, има само у погледу особине сналажљив. Поред тога, постоје особине које су у највећој мери заступљене код испитаника млађих од 26 година, али не и код испитаника старијих од 26 година. И обрнуто. Па тако, високим просечним оценама, испитаници старији од 26 година процењују да су код њих присутне осо-

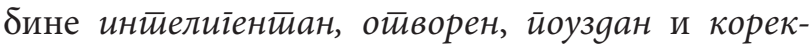

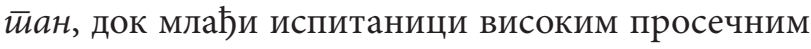
оценама процењују код себе присуство особина йойао, наgарен и самољубив. Особине које испитаници старији од 26 година више приписују себи спадају у категорију способности (интелигентан), односа према другим људима (отворен, коректан) и односа према раду и обавезама (поуздан). Аутоперцепцију спортиста са инвалидитетом млађих од 26 година, обележавају у највећој мери особине из категорије способности (надарен) и односа према себи (самољубив), али и једна особина из категорије емоционалних (топао). Такве аутоперцепције одговарају описима главне усмерености у појединим периодима живота (Erikson, 1994). У адолесценцији и млађем одраслом добу, особе су више усмерене на своје потенцијале и личну афирмацију, па и самољубље, док у каснијем одраслом добу фокус са себе прелази на друге људе и обавезе (йоузан). Па тако, млади спортисти са инвалидитетом, који су активно укључени у спорт којим се ठаве, вероватно имају циљеве које желе да остваре и усмерени су на изградњу односа према себи. Са друге стране, спортисти са инвалидитетом, старости од 27 до 60 година, вероватно су своје спортске амбиције и усмереност на себе остварили у мери која им дозвољава да фокус психолошког функционисања буде премештен на друге људе и интерперсоналне односе (Stevens,
1983). У сваком случају, без обзира на године старости и развојне потребе својствене животним фазама, сви испитаници показали су позитивну самоперцепцију.

Генерализација резултата добијених у односу на пол испитаника, чини се дискутабилна услед веома малог броја испитаних жена $(\mathrm{N}=5)$. Све особине које мушкарци спортисти са инвалидитетом у највећој мери приписују себи, појављују се и у аутоперцепцији жена спортиста са инвалидитетом (ойушиеиен, самойоуздан, весео, учйив, амбициозан, йоузан, корекииан, сналажтив, самоуверен), с тим што жене приписују себи и додатне особине (самокритиччан, наgарен, систие-

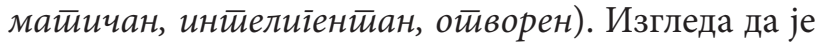
аутоперцепција жена шира и позитивнија, јер је далеко више особина оцењено високим просечним оценама, него код мушкараца, па се тако и процена две особине (ойуииен и самокритиччан) показала статистички значајном у корист спортисткиња са инвалидитетом. Судећи по особинама које су жене процениле високим оценама, а мушкарци не, чини се да жене спортисти са инвалидитетом, самокритичније и отвореније приступају самопроцени, али такође приписују себи и више талената и способности него мушкарци. Аутоперцепција мушкараца је ужа, са мање особина оцењених високим оценама, али и са више негативних особина оцењених ниским оценама. У сваком случају, важно је истаћи велике индивидуалне разлике код жена, а због малог броја испитаника потребно би било проверити добијене резултате на већем узорку.

Важна импликација овог истраживања је да спортисти са инвалидитетом имају позитивну самоперцепцију, која је у складу са описима оптималног и зрелог психолошког функционисања из психолошке литературе (Rodgers, 1942; Маслов, 1982; Erikson, 1994).

\section{ЗАКЉУЧАК}

У психолошкој литератури још увек има врло мало истраживања која се баве афирмацијом инвалидности као саставног дела идентитета особа са инвалидитетом, без обзира да ли је реч о урођеној или стеченој инвалидности (Dunn \& Burcaw, 2013). Позитиван општи селф-концепт и оптимално лично функционсиање (well-being) 
нису могући уколико инвалидност није афирмисана и укључена у лични идентитет, а истраживања показују да су особе са инвалидитетом врло често изоловане и упућене на круг људи са сличним сметњама (Olkin, 2008). Инклузија у ширу социјалну заједницу и друштво, могућа је управо преко спорта, а унапређење компетенција у области као што је спорт, евидентно може да доведе до позитивног трансфера емоционалне стабилности и позитивне самоперцепције на друге области, као и на општи селф-концепт (Martin, 2011; Scarpa, 2011).

Ово истраживање има неке лимите, које треба имати на уму приликом генерализације резултата. Прво, испитан је релативно мали број испитаника а веома широког опсега старости, па остаје отворено питање да ли би били добијени исти резултати да је у истраживању учествовао већи ठрој испитаника и/или да су испитаници били из уже старосне категорије. Треба имати у виду и да је овде реч о пригодном и на неки начин селектираном узорку, тј. о особама које су се активно бавиле или се баве спортом и зато је важно са опрезом генерализовати резултате на особе са инвалидитетом йер се. Последњих неколико деценија физичке активности и спорт, промовишу се

\section{ЛИТЕРАТУРА}

1. Bačanac, Lj., Milićević-Marinković, B., Kasum, G., \& Marinković, M. (2014). Competitive Anxiety, Self-Confidence and Psychological Skills in Top Athletes With and Without Disabilities: A Pilot Study. Facta univeristatis: Series sport and physical education, 12(2), 59-70.

2. Bandura, A. (1989). Human Agency in Social Cognitive Theory, American Psychologist, 44, 1175-1184.

3. Barič, R., Vlašić, J., \& Cecić-Erpič, S. (2014). Goal orientation and intrinsic motivation for physical education: Does perceived competence matter? Kinesiology, 46(1), 117-126.

4. Bogart, K.R. (2014). The role of disability self-concept in adaptation to congenital or acquired disability. Rehabilitation Psychology, 59(1), 107-115.

5. Brown, R. (2010). Prejudice in social psychology. 2nd edition. UK: Wiley-Blackwell.
У разним друштвима и културама, као средство одржавања и унапређења психофизичког здравља, што у случају особа са инвалидитетом не може увек да буде примењиво (Perrier \& Smith, 2014). Не треба изгубити из вида да неуспешност у спортским активностима може додатно да наруши оптимално психичко функционисање особа са инвалидитетом и да још више фокусира особу на инвалидност и тако ојача стереотипно негативно самоопажање (Shilling, 2008). У истраживању смо имали прилике да испитамо особе са инвалидитетом које су доживеле или доживљавају успешност и компетенцију у спортском контексту, али остаје отворено питање, каква би била самоперцепција особа са инвалидитетом, које су одустале од бављења спортским активностима. У овом истраживању каузална веза између самоперцепције и спорта није испитивана, већ је у фокусу истраживања била само слика о себи као таква. Уз унапређење метријских карактеристика инструмента за испитивање самоперцепције, у будућим истраживањима треба узети у обзир каузалну везу између спорта и самоперцепције особа са инвалидитетом, али и факторе који у том процесу могу да имају медијаторску улогу.

6. Gaskina, C., Andersen, M.B., \& Morris, T. (2009). Physical activity in the lifeof a woman with severe Cerebral Palsy: Showing competence and beingsocially connected. International Journal of Disability, Development and Education, 56(3), 285-299.

7. Gibson, B.E., Mistry, B., Smith, B., Yoshida, K.K., Abbott, D., Lindsay, S., \& Hamdani, Y. (2014). Becoming man: Gender, disability, and transitioning to adulthood. Health, 18 (1), 95-114.

8. Goodwin, D.L., Krohn, J., \& Kuhnle, A. (2004). Beyond the wheelchair: Theexperience of dance. Adapted Physical Activity Quarterly, 21, 229-247.

9. Goffman, E. (1963). Stigma: Notes on the management of spoiled identity. New York: Touchstone.

10. Greenlees, I. (2007). Person perception and sport performance. In: Jowett, S. \& Lawallee, D. (Eds). Social Psychology in Sport. Champaign, IL: Human Kinetics. 
11. DeCharms, R. (1983). Personal Causation, The Internal Affective Determinants of Behavior. Hillsdale, NJ: Lawrence Erlbaum Associates Publishers.

12. Deci, E.L. (1996). Why We Do What We Do: Understanding Self-Motivation. New York: Penguin Books.

13. Deci, E.L. \& Ryan, R.M. (2000). Self-Determination Theory and the Facilitation of Intrinsic Motivation, Social Development and Well-Being. American Psychologist, 55, 68-78.

14. Dunn, D.S., \& Burcaw, S. (2013). Disability identity: Exploring narrative accounts of disability. Rehabilitation Psychology, 58(2), 148-157.

15. Erikson, E. (1994). Identity and the life circe. Reissue edition. New York, NY: W.W.Norton \& Company, Inc.

16. James, W. (1890). The Principles of Psychology. Vol.1 \& Vol.2. At Classics in the History of Psychology, http://psychclassics.yorku.ca

17. Касум, Г. (2015). Сӣорй особа са инвалиgийейом. Београд: Факултет спорта и физичког васпитања.

18. Kasum, G., Lazarević, Lj., Jakovljević, S. \& Bačanac, Lj. (2011). Personality of male wheelchair basketball players and nonathletes persons with disability. Facta univeristatis: Series sport and physical education, 9(4), 407-415.

19. Lazić, A., \& Barić, R. (2013). Doprinos sporta kvaliteti života sportaša s invaliditetom. Hrvatski časopis za javno zdravstvo, 9(33). 244-246

20. Martin, J. (2011). Athletes with disabilities. In Morris, T., \& Terry, P. (Eds). The new sport and exercise psychology companion. Morgantown, WV: Fitness Information Technology.

21. Martin, J. (2010). Psychosocial dynamics of youth disability sport. Sport science review, 19(56), 49-69.

22. Martin, J.J. (2006). Psychosocial aspects of youth disability sport. Adapted Physical Activity Quarterly, 23, 65-77.

23. Martin, J. (2002). Training and performance self-efficacy, affect, and performance in wheelchair road racers. The Sport Psychologist, 16, 384-395.

24. Martin, J.J., \& Smith, K. (2002). Friendship quality in youth disability sport: Perceptions of a best friend. Adapted Physical Activity Quarterly, 19, 472-482.

25. Martin, J.J., Eklund, R.C., \& Adams Mushett, C. (1997). Factor structure oftheathletic identity measurement scale with athletes with disabilities. Adapted Physical Activity Quarterly, 14, $74-82$.

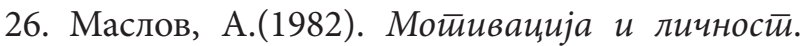
Београд: Нолит.

27. Mead, G.H. (1934). Mind, Self and the Society From the Standpoint of a Social Behaviorist. Chicago: Chicago University Press.

28. Misener, L., \& Darcy, S. (2013). Managing disability sport: From athletes with disabilities to inclusive organizational perspectives. Sport Management Review, 17, 1-7.

29. Младеновић, М. (2015). Самоопажање и мотивација за спорт код особа са сметњама и поремећајма у развоју. У: Рапаић, Д., Недовић, Г. Трунић, Н., Лазаревић, П., Младеновић, М., Лазаревић, С., Антић, Н., Милетић,

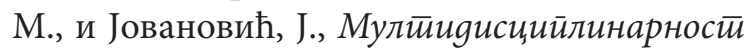
физичке куйуре за особе са смейтьма и йоремећајима у развоју (стр. 58-85). Београд: Факултет за физичку културу и менадзмент у спорту, Универзитета Сингидунум.

30. Mladenović, M., \& Marjanović, A. (2011). Some Differences in Sports Motivation of Young Football Players from Russia, Serbia and Montenegro. SportLogia, 7(2), 145-153.

31. Mladenović, M. (2010a). The link of a coach's perception of locus of control and his/her approach to athlets. SportLogia, 6(2), 34-41.

32. Младеновић, М. (2010б). Самомотиивачија. Београд: Задужбина Андрејевић.

33. Младеновић, М. (2007). Преgстиава о себи и мотиивачија за раg. Београд: Задужбина Андрејевић.

34. Olkin, R. (2008). Disability-Affirmative Therapy and case formulation: A template for understanding disability in a clinical context. Counseling \& Human Development, 39(8), 1-20.

35. Ostman, M., \& Kjellin, L. (2002) Stigma by association: psychological factors in relatives of people with mental illness. British Journal of Psychiatry, 181, 494-498. 
36. Perrier, M-J. \& Smith, B. (2014). Disability, sport and impaired bodies, a critical approach. In: Schindke, R.T, \& McGannon, K.R. The psychology of sub-culture in sport and physical activity: Critical perspectives, (pp. 95-106). London: Routledge.

37. Perrier, M-J., Smith, B., Strachan, S.M. \& Latimer-Cheung, A.E. (2014). Harratives of athletic identity after aquiring a permanent physical disability. Adapted Physical Activity Quarterly, 31, 106-124.

38. Perić, D., \& Tišma, M. (2014). Uloga motoričkog ponašanja dece predškolskog uzrasta u formiranju pojma o sebi. TIMS Acta, 8(1), 31-40.

39. Rogers, K. (1942). Counceling and Psychotherapy: A Hewer Concepts in Practice. Chicago: Houghton and Mifflin Company.

40. Ryan, R.M., \& Deci, E.L. (2006). Self-Regulation and the Problem of Human Autonomy: Does Psychology Heeds Choice, Self-Determination and Will? Journal of Personality, 74, 1557-1585.

41. Scarpa, S. (2011). Physical self-concept and self-esteem in adolescents and young adults with and without physical disability: the role of sport participation. European Journal of Adapted Physical Activity, 4(1),38-53.

42. Shapiro, J. (1993). Ho pity: People with disabilities forging a new civil rights movement. Hew York, HY: Random House, Inc.

43. Shilling, C. (2008). Changing bodies: Habit, crisis and creativity. London: Sage.

44. Smith, B. (2015). Disability, sport and athletic identity: from a paralympicathlete to retirement and a disabled person. In Schmid, O. \& Seiler, R. (Eds). Proceedings of 14th European Congress of Sport Psychology: Theories and applications for performance, health and humanity. (pp. 229230). Bern: University of Bern.

45. Smyth, M.M., \& Anderson, H.I. (2000). Coping with clumsiness in the schoolplayground: Social and physical play in children with coordination impairments.British Journal of Developmental Psychology, 18, 389-413.

46. Stevens, R. (1983). Erik Erikson: An introduction. Hew York: St. Martin's.

47. Stewart, R.A., Powell, G.A., \& Chetwynd, S.J. (1979). Person perception and stereotyping. England: Saxon House.

48. Feltz, D.L., Short, S.E., \& Sullivan, P.J. (2008). Self-efficacy in sport. Champaing, IL: Human Kinetics.

49. Hastorf, A.H., Schneider, D.J., \& Polefka, J. (1970). Person perception. Reading, Massachusetts: Addison-Wesley Publishing Company.

50. Heider, F. (1958). Perceiving the Other Person. In: Tagiuri, R. \& Petrullo, L. (Eds.). Person perception and interpersonal behaviour. Stanford, California: Stanford University Press.

51. Хавелка, N. (1992). Социјална иеериейција. Београд: Завод за уџбенике и наставна средства.

52. Chirkov, V.I., Ryan, R.M., Kim, Y., \& Kaplan, U. (2003). Differentiating Autonomy From Individualism and Independence: A Self-Determination Theory Perspective on Internalization of Cultural Orientations and Well-Being. Journal of Personality and Social Psychology, 84, 97-110.

53. Chirkov, V.I., Ryan, R.M., \& Wellness, C. (2005). Cultural Context and Psychological Needs in Canada and Brasil: Testing a Self-Determination Approach to Internalization of Cultural Practices, Identity and Well-Being. Journal of Cross-Cultural Psychology, 36, 423-443.

54. Crocker, J., \& Major, B. (1989). Social stigma and self-esteem: The self-protective properties of stigma. Psychological Review, 96(4), 608-630.

55. Шиљак, В., Стефановић, Ђ., Плакона, Е., Касум, Г. и Авдибашић-Вукадиновић, Н. (2010). Феномен Летњих параолимпијских игара. Физичка кулитура, 64(2), 68-75. 


\section{SELBSTWAHRNEHMUNG BEHINDERTER SPORTLER}

\section{Zusammenfassung}

Psychologische Untersuchungen zeigen, dass andere Menschen sehr oft Personen mit einer Form von Behinderung auf eine stereotypisierte Weise wahrnehmen. Behinderte Sportler werden von anderen Menschen häufig als „jammervoll“ oder als „Superhelden“ erlebt. Neben Vorurteilen und einer stereotypisierten sozialen Wahrnehmung sind behinderte Personen häufiger als nichtbehinderte Personen mit einer Ineffizienz auf dem Sportgelände konfrontiert, womit Sport zu einem zweischneidigen Schwert werden kann, das das Selbstbild fördern oder zerschlagen kann. Das Ziel dieser Untersuchung war es, festzustellen, wie behinderte Sportler sich selbst sehen, wie ihre realistische Selbstwahrnehmung aussieht? Es wurde davon ausgegangen, dass bedeutende Unterschiede auf Grund des Alters und des Geschlechts der Prüflinge vorhanden sein könnten. Als Instrument wurde ein Inventar für Selbstwahrnehmung angewendet, zusammengesetzt aus 30 Persönlichkeitsattributen, die auf einer 4-stüfigen Skala bewertet werden. Befragt wurden 19 behinderte Sportler im Alter von 14 bis 60 Jahren. 8 Prüflinge waren im Alter bis 26 Jahren, 11 waren über 26 Jahre alt; 14 Prüflinge waren Männer, 5 waren Frauen. Die Ergebnisse haben gezeigt, dass statistisch bedeutende Unterschiede in der Selbstwahrnehmung bei Prüflingen unterschiedlichen Alters und Geschlechts vorhanden sind. Die Selbstwahrnehmung der befragten behinderten Sportler wird von Attributen dominiert, die auf eine positive Selbstwahrnehmung und Selbstbild hinweisen (zB. selbstsicher, fröhlich, locker, ehrgeizig, korrekt). Ungeachtet dessen, dass eine relativ kleine Anzahl von Prüflingen an dieser Untersuchung teilnahm und nicht die direkte Verbindung von Selbstwahrnehmung und Sportaktivitäten untersucht wurde, kann man sagen, dass Implikationen vorhanden sind, die im Einklang mit dem allgemeinen Trend von psychologischen Untersuchungen stehen, die einen positiven Einfluss von Sportaktivitäten auf die Verbesserung des Selbstkonzepts von behinderten Personen bestätigen.

Schlüsselwörter: STEREOTYP / SOZIALE WAHRNEHMUNG / SPORT / SELBSTBESCHREIBUNG

Рад је настао у оквиру пројекта „Ефекти примењене физичке активности на локомоторни, метаболички, психо-социјални и образовни статус српског становништва“, $\delta$ р. III47015, а део је подпројекта „Ефекти примењене физичке активности на локо-моторни, метаболички, психо-социјални и образовни статус популације особа са инвалидитетом Р. Србије“.

Примљен: 19.02.2017.

Прихваћен: 27.04.2017. 